\title{
Modified Gold Nanoparticles for Efficient Delivery of Betulinic Acid to Cancer Cell Mitochondria
}

\author{
Olakunle Oladimeji, Jude Akinyelu, Aliscia Daniels and Moganavelli Singh * (D)
}

check for

updates

Citation: Oladimeji, O.; Akinyelu, J.; Daniels, A.; Singh, M. Modified Gold Nanoparticles for Efficient Delivery of Betulinic Acid to Cancer Cell Mitochondria. Int. J. Mol. Sci. 2021, 22, 5072. https://doi.org/10.3390/ ijms22105072

Academic Editors:

Monica Terracciano and

Chiara Tramontano

Received: 4 April 2021

Accepted: 28 April 2021

Published: 11 May 2021

Publisher's Note: MDPI stays neutral with regard to jurisdictional claims in published maps and institutional affiliations.

Copyright: (c) 2021 by the authors. Licensee MDPI, Basel, Switzerland. This article is an open access article distributed under the terms and conditions of the Creative Commons Attribution (CC BY) license (https:// creativecommons.org/licenses/by/ $4.0 /)$.
Nano-Gene and Drug Delivery Group, Discipline of Biochemistry, University of KwaZulu-Natal, Private Bag X54001, Durban 4000, South Africa; kunle1433@gmail.com (O.O.); jude.akinyelu@fuoye.edu.ng (J.A.); DanielsA@ukzn.ac.za (A.D.)

* Correspondence: singhm1@ukzn.ac.za; Tel.: +27-3-1260-7170

\begin{abstract}
Advances in nanomedicine have seen the adaptation of nanoparticles (NPs) for subcellular delivery for enhanced therapeutic impact and reduced side effects. The pivotal role of the mitochondria in apoptosis and their potential as a target in cancers enables selective induction of cancer cell death. In this study, we examined the mitochondrial targeted delivery of betulinic acid (BA) by the mitochondriotropic $\mathrm{TPP}^{+}$-functionalized epigallocatechin gallate (EGCG)-capped gold NPs (AuNPs), comparing the impact of polyethylene glycol (PEG) and poly-L-lysine-graft-polyethylene glycol (PLL-g-PEG) copolymer on delivery efficacy. This included the assessment of their cellular uptake, mitochondrial localization and efficacy as therapeutic delivery platforms for BA in the human Caco-2, HeLa and MCF-7 cancer cell lines. These mitochondrial-targeted nanocomplexes demonstrated significant inhibition of cancer cell growth, with targeted nanocomplexes recording $\mathrm{IC}_{50}$ values in the range of 3.12-13.2 $\mu \mathrm{M}$ compared to that of the free BA $(9.74-36.31 \mu \mathrm{M})$ in vitro, demonstrating the merit of mitochondrial targeting. Their mechanisms of action implicated high amplitude mitochondrial depolarization, caspases $3 / 7$ activation, with an associated arrest at the G0/G1 phase of the cell cycle. This nano-delivery system is a potentially viable platform for mitochondrial-targeted delivery of BA and highlights mitochondrial targeting as an option in cancer therapy.
\end{abstract}

Keywords: mitochondrial targeting; gold nanoparticles; cancer chemotherapy; drug delivery; betulinic acid; laminin receptor

\section{Introduction}

The continuous rise in cancer-associated mortality against a backdrop of advances in drug discovery highlights the prevailing challenges of existing therapeutic interventions for cancer. Cancer remains the second leading cause of death worldwide, with approximately 9.6 million deaths recorded in 2018 and another 18 million new cases reported in the same year [1]. While traditional treatment approaches such as surgery and radiotherapy have their limitations, the major demerits of chemotherapy are poor bioavailability, a low therapeutic index, and a marked increase in normal cell cytotoxicity on any compensatory dose increase [2].

The idea of a "magic bullet" in the treatment of diseases proposed by Paul Ehrlich, suggesting the precise delivery of therapeutics to their active sites may have inspired the targeted delivery concept, which has gained traction in recent times [3]. In cancer therapy, the application of this concept has seen the development of nano-delivery systems engineered to target and accumulate in cancerous tissues. Their application significantly enhances drug pharmacokinetics, minimizes side effects, and improves the drug's therapeutic index [2,4]. Further advances in this research area have also led to the introduction of optimized systems suitable for efficient delivery of the cargo to molecular targets localized in intracellular organelles [5]. Recent reports revealed that nanoformulations targeted to organelles such as the mitochondria, endosome, lysosome, nucleus, ribosome and the Golgi apparatus, demonstrated efficacy in the delivery of genes, proteins and drugs, thus 
highlighting their potential application in clinical scenarios [6,7]. It is anticipated that the preferential targeting of subcellular compartments with nanomedicines would significantly improve treatment selectivity and biocompatibility, with the potential of achieving higher therapeutic indices at lower doses. The central role of mitochondria in bioenergetics and apoptosis signaling has made them a focus of clinical research, and a therapeutic target for diseases in recent years. Although apoptosis is a well-regulated physiological process, certain extracellular agents have been shown to modulate mitochondria function and induce apoptosis, thus presenting an in-road to preferentially targeting the organelle in related disease conditions [8].

Betulinic acid (BA) is a pentacyclic triterpenoid, from a subclass of terpenes composed of isopentenyl pyrophosphate oligomers, that have been studied for their medicinal potential $[9,10]$. BA demonstrates potent activity against bacterial and viral infections, inflammation, malaria, and cancer $[10,11]$. Research has shown that the anticancer effect of $\mathrm{BA}$ is linked to its impact on the mitochondria. BA induces membrane permeability transition (MPT) in cancer mitochondria, consequently triggering the dissipation of mitochondrial membrane potential, cytochrome $\mathrm{c}$ release, caspase activation and finally, apoptosis [12-14]. A major drawback to BA's clinical potential is its poor solubility, which, coupled with other common limitations such as high blood clearance and low specificity, impacts its efficacy in vivo. To improve the therapeutic effectiveness of the drug on the cancer cell mitochondria, a nano-delivery system with the capacity to successfully navigate physiological and cellular barriers and ensure the delivery of the payload to the mitochondria for maximum impact is imperative [15].

Biocompatibility is a critical factor in the efficacy of nano-delivery platforms. The green or organic synthesis of inorganic nanoparticles (NPs) offers, among other things, the elimination of toxicities associated with chemical synthesis, as well as the transfer of bioactive properties from plant-based reductants. Green synthesis of inorganic NPs employs the reductive power of bio-extracts to affect the reduction of metallic salts from their initial oxidative state to zero [16]. Generally, green synthesized NPs adopt the unique features of bio-extracts employed in their synthesis. Organic synthesis with extracts from fungi, algae, plants, and bacteria have given rise to NPs with inherent antioxidant, antibacterial and self-targeting properties. EGCG has been reported to show an affinity for the $67 \mathrm{kD}$ laminin receptor (67LR), that is overexpressed in most aggressive tumors [17-20]. The laminin receptor-dependent uptake of EGCG-reduced radioactive gold NPs (AuNPs) by cancer cells has been reported [21]. Considering the potential inherent in the preferential targeting of therapeutics to intracellular sites of action to bring about improved bioavailability and therapeutic efficacy at a lower dose with tolerable side effects, we have studied the capacity of EGCG-capped, laminin receptor-avid AuNPs for mitochondrial-targeted delivery of BA in selected cancer cells in vitro. The decoration of an inorganic NP surface with biodegradable polymers has been reported to improve NP biocompatibility, stability, and influence cargo release [22]. PLL, a biocompatible and biodegradable polymer of the amino acid L-lysine exerts these effects, and apart from the provision of functional amino groups for the easy conjugation of other components, its net electropositive charge promotes an electrostatic interaction with the electronegative cellular membrane, aiding NP uptake [23,24]. The pegylation of NPs, among other things, confers stealth properties and correlates with increased residence time in vivo [22,25]. Therefore, we assessed the impact of surface design on NP efficiency, comparing the activities of PEG-coated nanocomplexes to the PLL-g-PEG-coated variant. To the best of our knowledge, this study is the first attempt at preferentially targeting BA to the mitochondria.

\section{Results}

\subsection{Synthesis and Functionalization of EGCG-Capped AuNPs}

EGCG-capped AuNPs were synthesized by the reduction of gold (III) chloride with the green tea polyphenol, EGCG, as illustrated in Figure 1. Surface functionalization of EGCG-capped NPs involved coating with either PEG, or a graft polymer of PLL-PEG (PLL- 
g-PEG) to produce two polymer-coated variants, the Au-PEG and the Au-[PLL-g-PEG] NPs, respectively. Further functionalization included the conjugation of the drug BA, and the lipophilic moiety, triphenylphosphine $\left(\mathrm{TPP}^{+}\right)$for enhanced mitochondria localization.

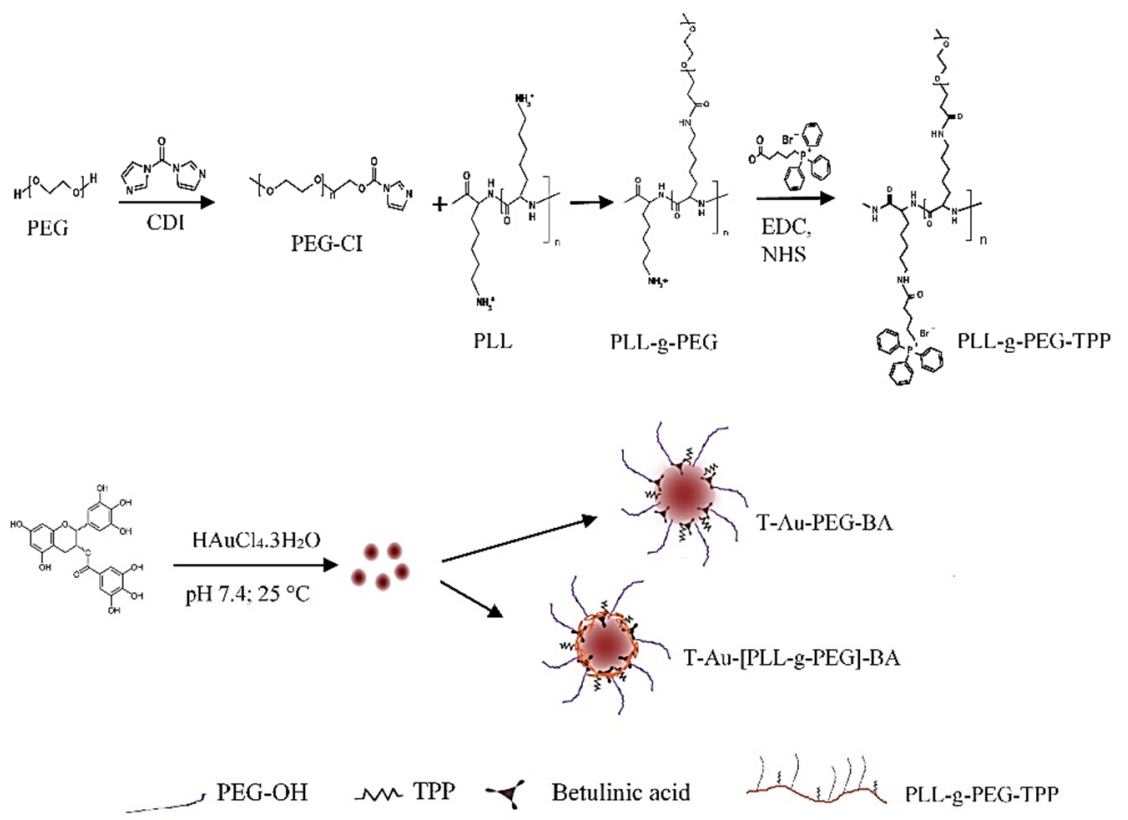

Figure 1. The synthesis of EGCG-capped NPs, and the engineering of the targeted T-Au-PEG-BA and T-Au-[PLL-g-PEG]-BA nanoparticles.

\subsection{UV-Vis Spectroscopy}

The synthesis and functionalization of EGCG-capped AuNPs were monitored by UV-vis spectroscopy. Inorganic NPs generally show distinct optical properties, which are representative of their physical features such as size and stability [26,27]. The successful functionalization of a NP results in changes in the oscillation state of its surface electrons, otherwise referred to as localized surface plasmon resonance (SPR), manifesting as change in optical properties. AuNPs generally show a strong absorbance peak between 500 and $600 \mathrm{~nm}$, and in this study, EGCG capped AuNPs had a strong absorbance peak at $524 \mathrm{~nm}$, comparable to citrate capped AuNPs $(520 \mathrm{~nm})[28,29]$. Subsequent surface designs resulted in band shifts and reduction in peak intensities in Au-PEG (522 nm), T-Au-PEG and TAu-PEG-BA (542 nm), with the blueshift on PEG conjugation indicating a reduction in size, the redshift to $542 \mathrm{~nm}$ on $\mathrm{TPP}^{+}$and BA showing a slight reduction in NP stability compared to unfunctionalized AuNPs, with the widening of the peak indicating an increase in dispersity. Similarly, the coating with PLL-g-PEG resulted in a band shift to $534 \mathrm{~nm}$, while the conjugation of TPP+ and BA resulted in a shift to 541 and $533 \mathrm{~nm}$, respectively (Figure 2), indicating an increase in size or slight reduction in stability compared to the unfunctionalized AuNPs. Overall, the PLL-g-PEG coated NPs seemed to be the more stable of the two designs. The band shifts and reduction in peak intensity are suggestive of a successful binding of the polymer and drug.

\subsection{Fourier-Transform Infrared Spectroscopy (FTIR)}

The frequency of vibration of molecules upon absorption of electrochemical radiation is distinctive for individual molecules. These vibrations, represented as band shifts at characteristic wavelengths in the IR spectrum are applied in the analysis of organic compounds, especially in the identification of functional groups [30]. The synthesis and subsequent functionalization of NPs with polymers, drug, and the targeting moiety were monitored and confirmed by FTIR analysis. As represented in Figure 3, EGCG capped AuNPs showed stretching vibrations of $\mathrm{O}-\mathrm{H}\left(3400 \mathrm{~cm}^{-1}\right)$ and $\mathrm{C}-\mathrm{H}\left(3000 \mathrm{~cm}^{-1}\right)$ of the 
aromatic rings characteristic of the polyphenol groups of EGCG. In addition, the aromatic skeletal vibrations at $1630 \mathrm{~cm}^{-1}$ also of the EGCG moiety further confirmed the successful capping of AuNPs by the polyphenol. The successful functionalization of AuNPs with PEG was evident from the stronger peak at 3000 and $1190 \mathrm{~cm}^{-1}$ due to the stretching vibrations of the $\mathrm{C}-\mathrm{H}$ bonds and $\mathrm{C}-\mathrm{O}$ bonds of the polymer, respectively.
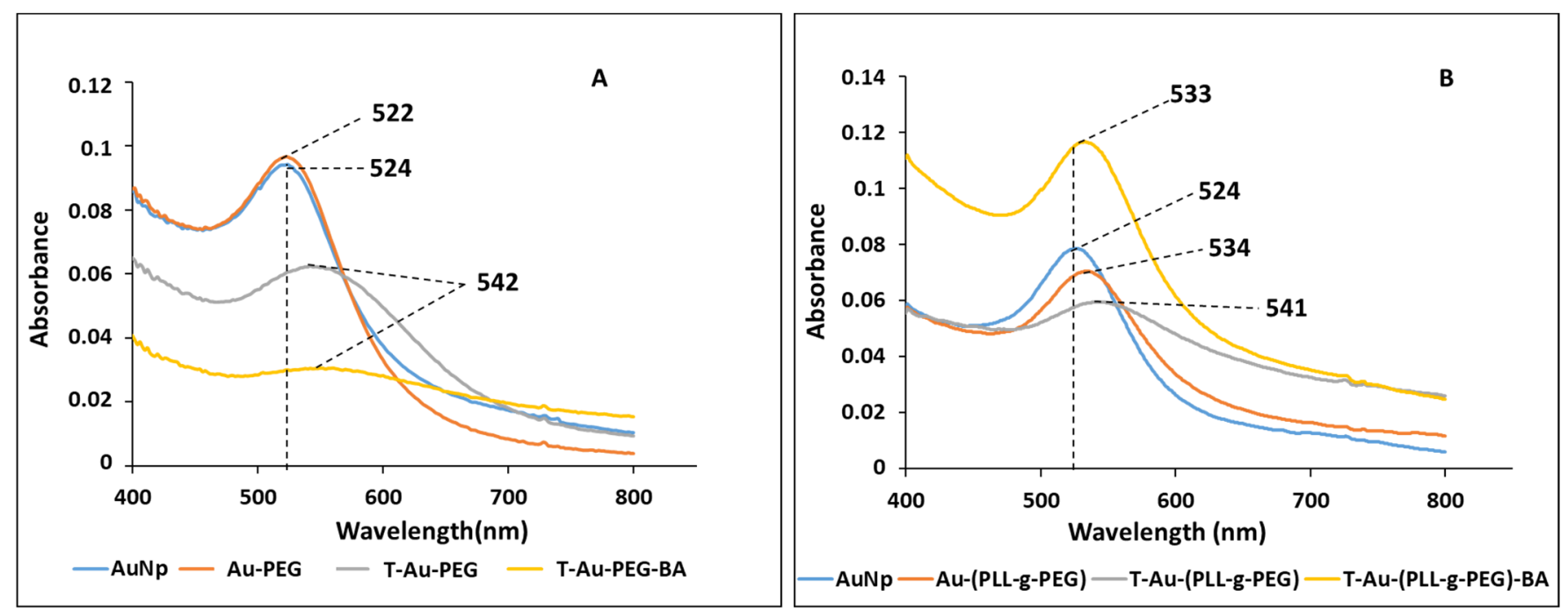

Figure 2. UV-vis of nanoparticles and drug nanocomplexes showing changes in surface plasmon resonance: (A) PEG functionalized AuNPs; (B) PLL-g-PEG coated AuNPs.

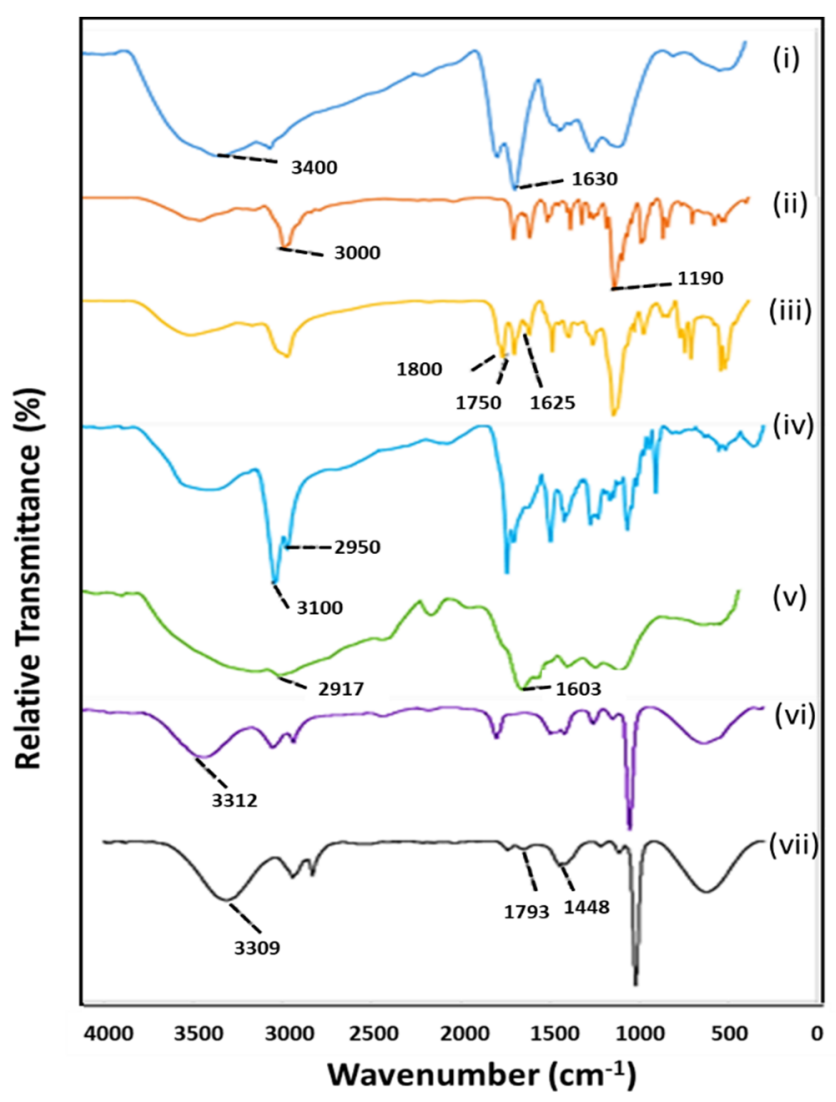

Figure 3. FTIR of nanoparticles showing changes in bond vibrations of respective functional groups. (i) AuNP, (ii) Au-PEG, (iii) T-Au-PEG, (iv) T-Au-PEG-BA, (v) Au-[PLL-g-PEG], (vi) T-Au-[PLL-gPEG], (vii) T-Au-[PLL-g-PEG]-BA. 
The lipophilic cation TPP+ moiety of the targeted NP (T-Au-PEG) coupled by Steglich esterification to the $\mathrm{OH}$ groups of Au-PEG, showed characteristic skeletal vibrations of its three aromatic rings at 1800, 1750 and $1625 \mathrm{~cm}^{-1}$. Similarly, the very strong vibrations of the $\mathrm{C}=\mathrm{O}$ group at $1681 \mathrm{~cm}^{-1}$, and those of the $\mathrm{CH}_{3}, \mathrm{CH}_{2}$, and $\mathrm{CH}$, at 2950 and $3000 \mathrm{~cm}^{-1}$ in T-Au-PEG-BA, confirmed the loading of BA into the NPs [31]. The coating of NPs with PLL-g-PEG to yield the Au-PLL-g-PEG, showed the characteristic stretch vibration for the repeating $\mathrm{CH}_{2}$ groups of PLL at $2917 \mathrm{~cm}^{-1}$, and the secondary amine groups $(\mathrm{NH})$ at $1603 \mathrm{~cm}^{-1}$. The subsequent conjugation of $\mathrm{TPP}^{+}$is evident from the stretching vibrations of the $\mathrm{C}-\mathrm{H}$ bonds of the benzene rings at $3312 \mathrm{~cm}^{-1}$, and the stretching vibration of $\mathrm{CH}_{2}$ and $\mathrm{CH}_{3}$ groups at 2945 and $2835 \mathrm{~cm}^{-1}$, respectively. The loading of BA in T-Au-[PLL-gPEG]-BA was confirmed by the amplification of IR peaks at $3309 \mathrm{~cm}^{-1}$ for $\mathrm{OH}$ stretching vibration, and at $2943 \mathrm{~cm}^{-1}$ for $\mathrm{CH}_{3}, \mathrm{CH}_{2}$ and $\mathrm{CH}$ groups. Furthermore, the bands at $1793 \mathrm{~cm}^{-1}$ (shoulder) and $1648 \mathrm{~cm}^{-1}$ are representative of the $\mathrm{C}=\mathrm{O}$ group of $\mathrm{BA}$, while the signal at $1448 \mathrm{~cm}^{-1}$ is due to the bending vibrations of the $\mathrm{CH}_{3}$ and $\mathrm{CH}_{2}$ groups of the aliphatic ring of the drug [30].

\subsection{Drug Loading, TEM and NTA}

Au-PEG-BA and T-Au-PEG-BA had loading efficiencies of $25.4 \%$, while Au-PLL-gPEG-BA and T-Au-PLL-g-PEG-BA had loading efficiencies of $\sim 21 \%$ (Table 1). Table 1 also reflects the NTA hydrodynamic size, zeta potential and polydispersity indices of all NPs.

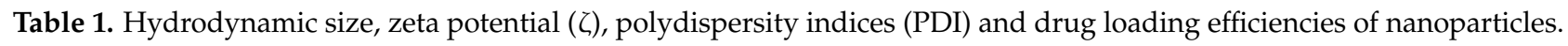

\begin{tabular}{ccccc}
\hline NPs & Hydrodynamic Size $(\mathbf{n m})$ & PDI & $\begin{array}{c}\zeta \text { Potential } \\
(\mathbf{m V})\end{array}$ & BA Loading Efficiency $\mathbf{( \% )}$ \\
\hline EGCG-AuNP & $127.3 \pm 3.1$ & 0.10 & $-28.3 \pm 1.6$ & - \\
Au-PEG-BA & $110.1 \pm 5.3$ & 0.22 & $-25.0 \pm 0.9$ & $25.4 \pm 0.04$ \\
T-Au-PEG-BA & $97.1 \pm 2.5$ & 0.035 & $-23.1 \pm 1.1$ & $25.4 \pm 0.12$ \\
Au-[PLL-g-PEG]-BA & $147.2 \pm 4.7$ & 0.13 & $+11.8 \pm 1.6$ & $21.0 \pm 1.2$ \\
T-Au-[PLL-g-PEG]-BA & $119.2 \pm 3.5$ & 0.11 & $+23.4 \pm 0.5$ & $21.0 \pm 0.7$ \\
\hline
\end{tabular}

TEM showed stable, spherical NPs (Figure 4) with an average size diameter of $15 \mathrm{~nm}$. Analysis following surface design showed negligible change in particle size, and no agglomeration. The hydrodynamic diameter (NTA) for AuNPs was in the $127 \mathrm{~nm}$ range, while subsequent modification resulted in a reduction in the diameter to 110.1 and $97.1 \mathrm{~nm}$ for Au-PEG-BA and T-Au-PEG-BA, respectively. Upon coating with PLL-g-PEG and TPP ${ }^{+}$ PLL-g-PEG, an increase in NP diameter to $147.2 \mathrm{~nm}$ and a reduction to $119 \mathrm{~nm}$ were recorded, respectively (Table 1). The polydispersity index (PDI) provides information on the size distribution of NPs. Generally, NPs with low PDI values are monodispersed and uniform in size [32]. The PDI estimations for the nanocomplexes studied suggests moderate dispersity with values closer to 0.1, except for the Au-PEG-BA nano-construct with a PDI value of 0.22 , suggesting some polydispersity.

The zeta potential measurement which informs on the surface charge of the NP with respect to that of the conducting fluid, in this case water ( $\mathrm{pH} 7)$, is a marker for NP stability and biomolecular interactions. The PEG functionalization of the AuNPs only effected marginal changes, with the zeta potential remaining negative even upon further functionalization with $\mathrm{TPP}^{+}$. Conversely, coating with the cationic PLL-g-PEG and TPP ${ }^{+}$-PLL-g-PEG resulted in positive surface charge for the NPs, of 11.8 and $23.4 \mathrm{mV}$, respectively. Overall, the zeta potentials recorded indicated that the nanocomplexes were stable, however, the negative charge of T-Au-PEG-BA and Au-PEG-BA could have adversely influenced their interaction with the cell and mitochondria due to the negative potentials $(\Psi)$ of both membranes. 

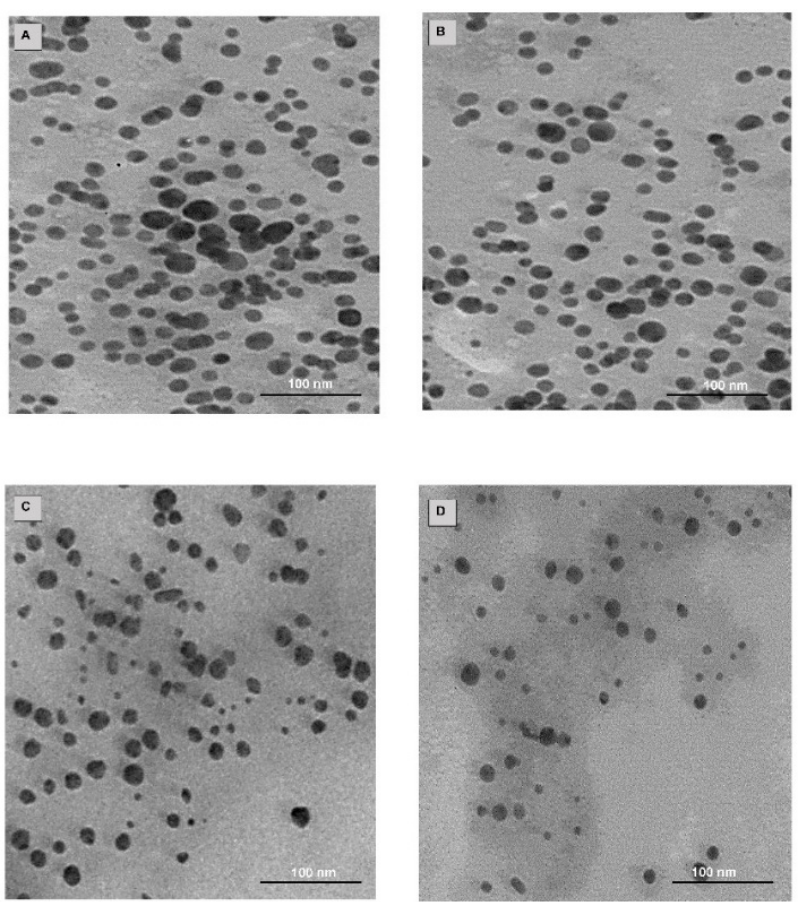

Figure 4. TEM images of nanoparticles: (A) AuNPs, (B) AuNP-BA, (C) T-Au-PEG-BA, (D) T-Au[PLL-g-PEG]-BA.

\subsection{Cellular Uptake and Mitochondrial Targeting}

The ability of NPs to cross the cell membrane bilayer and translocate efficiently to subcellular targets is pivotal to their application in therapeutic delivery. Given earlier reports on the affinity of EGCG for the 67-kDa laminin receptor [21,33], the laminin receptor dependent uptake of T-Au-PEG and T-Au-PLL-g-PEG was studied in the HeLa cell line due to its high expression of the receptor [34]. Cellular uptake in cells preincubated with the laminin receptor antibody were generally lower compared to cells not treated with the antibody (Figure 5). For T-Au-PEG NPs, uptake was significantly lower in preincubated cells (T-Au-PEG: 51980.98 particles/ $\mu$ g protein; T-Au-PEG/+Ab: $12,059.37$ particles / $\mu \mathrm{g}$ protein), thus showing a strong dependence on laminin receptor mediated uptake. Although recording a lower level of uptake compared to T-Au-PEG, a statistically significant reduction in uptake upon receptor blocking was also recorded for the T-Au-[PLL-g-PEG] NPs with 30,451.87 particles/ $\mu$ g protein, and T-Au-[PLL-g-PEG]/+Ab with 11,273.19 particles/ $\mu$ g protein). The lower levels observed for T-Au-[PLL-g-PEG] NPs can be attributed to their larger size which may have an impact on the efficiency of NP uptake.

The distribution of NPs between the cytoplasm and mitochondria, in the Caco-2, MCF7 and HeLa cell lines, was determined after a $12 \mathrm{~h}$ period by the differential centrifugation of the cell lysate to obtain the cytoplasmic and mitochondrial fractions, and thereafter analyzed by ICP-OES to obtain a quantitative estimate of the mitochondrial localization efficiency of these NPs. Significant mitochondrial localization was achieved by T-Au-PEG and T-Au-[PLL-g-PEG] NPs compared to their untargeted counterparts (Au-PEG and $\mathrm{Au}$-[PLL-g-PEG]) (Figure 6).

Furthermore, in all three cell lines, mitochondrial localization was higher for T-Au[PLL-g-PEG] NPs compared to T-Au-PEG NPs. Interestingly, mitochondrial localization for the two targeted NPs was highest in the MCF-7 and lowest in Caco-2 cells. While the presented data does not establish the rate of NP uptake in the different cell lines, it suggests that the intracellular trafficking of NPs may vary for the respective cell lines. 


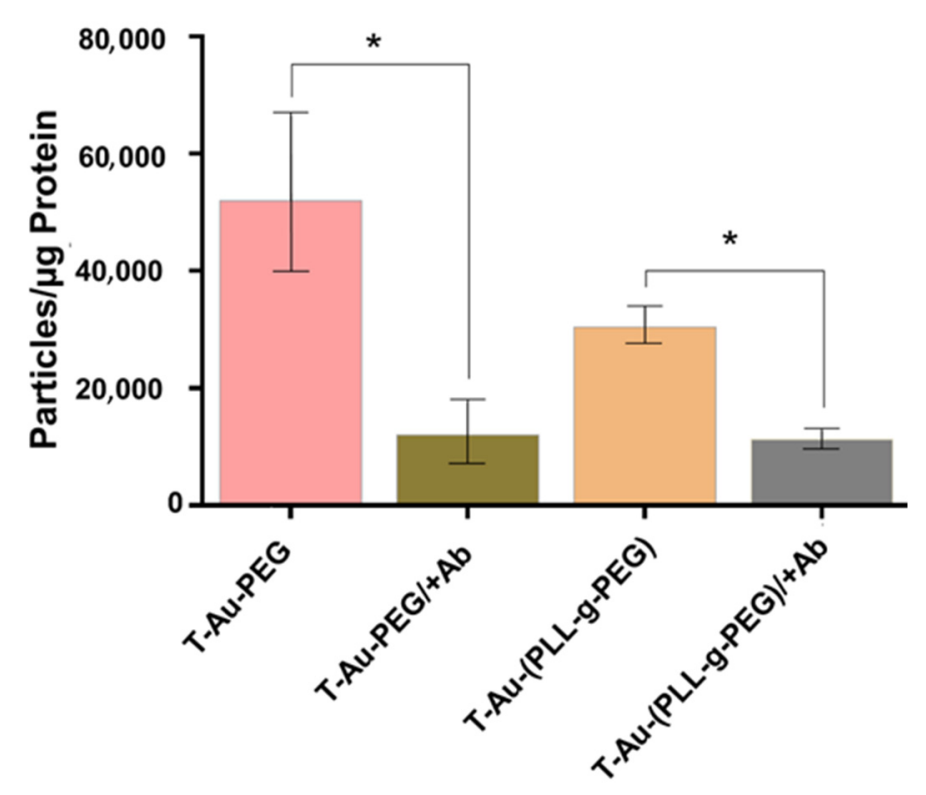

Figure 5. Graphical representation of the laminin dependent uptake of targeted nanoparticles in HeLa cells. Data is represented as mean $\pm \operatorname{SD}(n=3) .\left({ }^{*} p<0.05\right)$.

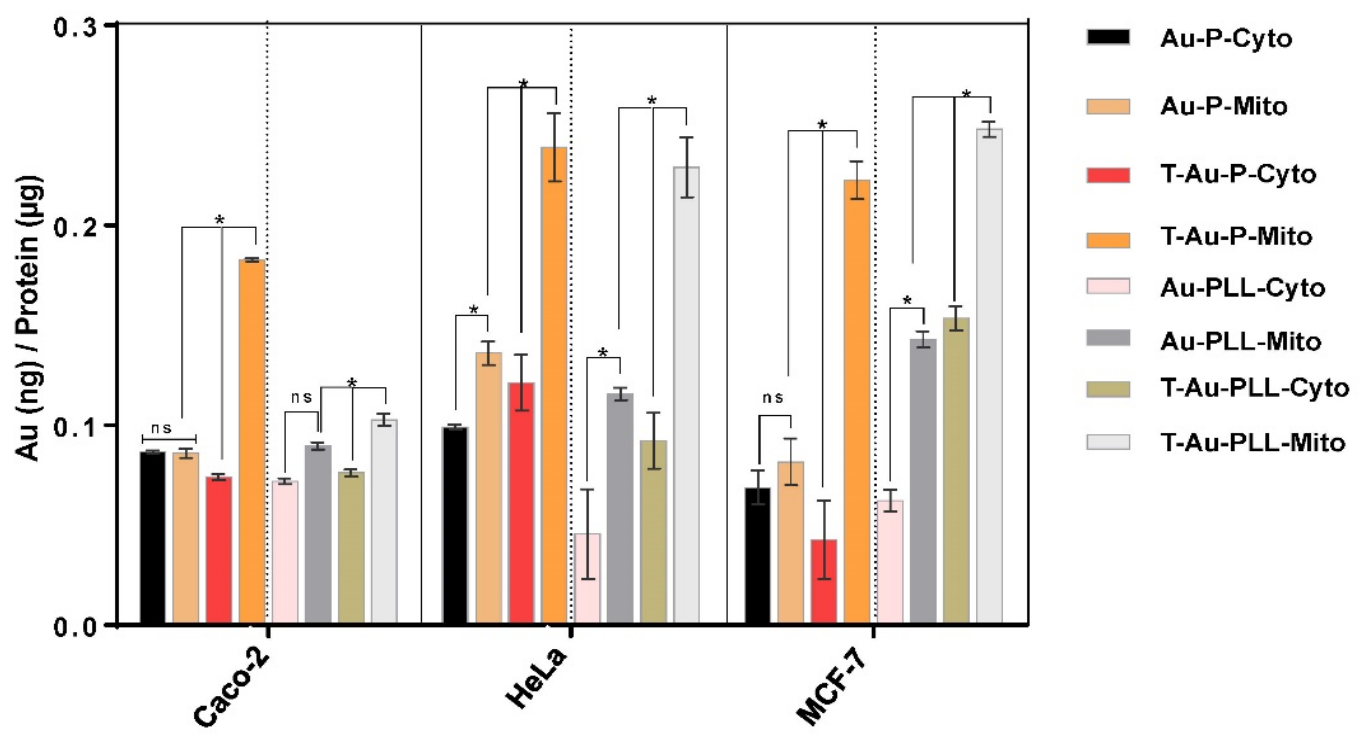

Figure 6. Cytosolic and mitochondrial distribution of mitochondrial targeted and nontargeted nanoparticles as determined by ICP-OES. Data is represented as mean $\pm \operatorname{SD}(n=3){ }^{*} p<0.05$; $\mathrm{ns}=$ no significant difference.

\subsection{Cytotoxicity}

The impact of targeted and untargeted nanocomplexes, and the free drug on cell proliferation was assessed in the HEK293, Caco-2, HeLa and MCF-7 cells, using the colorimetric MTT assay (Figure 7).

The drug-loaded nanocomplexes tested were reported in the concentrations of their respective BA content $(\mu \mathrm{M})$ for easy comparison with free BA, while the corresponding volume of drug-loaded NPs used for each drug concentration was adopted for drug free nanocomplexes. Negligible cytotoxicity was recorded for all NPs in the HEK293 cells, suggesting that these normal cells showed good tolerance to these treatments. Similarly, drug loaded NPs showed low cytotoxicity, while free BA recorded marked cytotoxicity in normal HEK293 cells, recording an $\mathrm{IC}_{50}$ value of $32.4 \mu \mathrm{M}$ compared to $>80 \mu \mathrm{M}$ recorded for 
T-Au-PEG-BA and T-Au[PLL-g-PEG]-BA. The efficacy of the NPs in mitochondrial accumulation, and subsequent delivery of their cargo is evident from the low $\mathrm{IC}_{50}$ values recorded for targeted nanocomplexes compared to their nontargeted counterparts and the free drug. As presented in Table 2, the estimated $\mathrm{IC}_{50}$ values for T-Au-PEG-BA in Caco-2, HeLa and MCF-7 cells are 3.13, 6.51 and $13.2 \mu \mathrm{M}$, respectively, which are markedly low compared to the 8.20, 25.37 and $53.74 \mu \mathrm{M}$ recorded for Au-PEG-BA; and 9.74, 17.73 and $36.31 \mu \mathrm{M}$ recorded for free drug. Similarly, T-Au[PLL-g-PEG]-BA inhibited proliferation at levels significantly higher compared to $\mathrm{Au}$ [PLL-g-PEG]-BA and BA, recording low $\mathrm{IC}_{50}$ values in Caco-2, HeLa and MCF-7 cells $(3.12,3.26$ and $13.13 \mu \mathrm{M}$, respectively), compared to the higher $\mathrm{IC}_{50}$ values recorded by Au[PLL-g-PEG]-BA $(5.72,23.64$ and $22.25 \mu \mathrm{M})$ and free BA $(9.74,17.73,36.31 \mu \mathrm{M})$ in the same cells. In spite of the lower mitochondrial accumulation seen in T-Au-PEG-BA (Figure 6), its impact on cellular proliferation is not different from that of T-Au[PLL-g-PEG]-BA, which suggests the possibility of extra-mitochondrial targets for T-Au-PEG-BA.
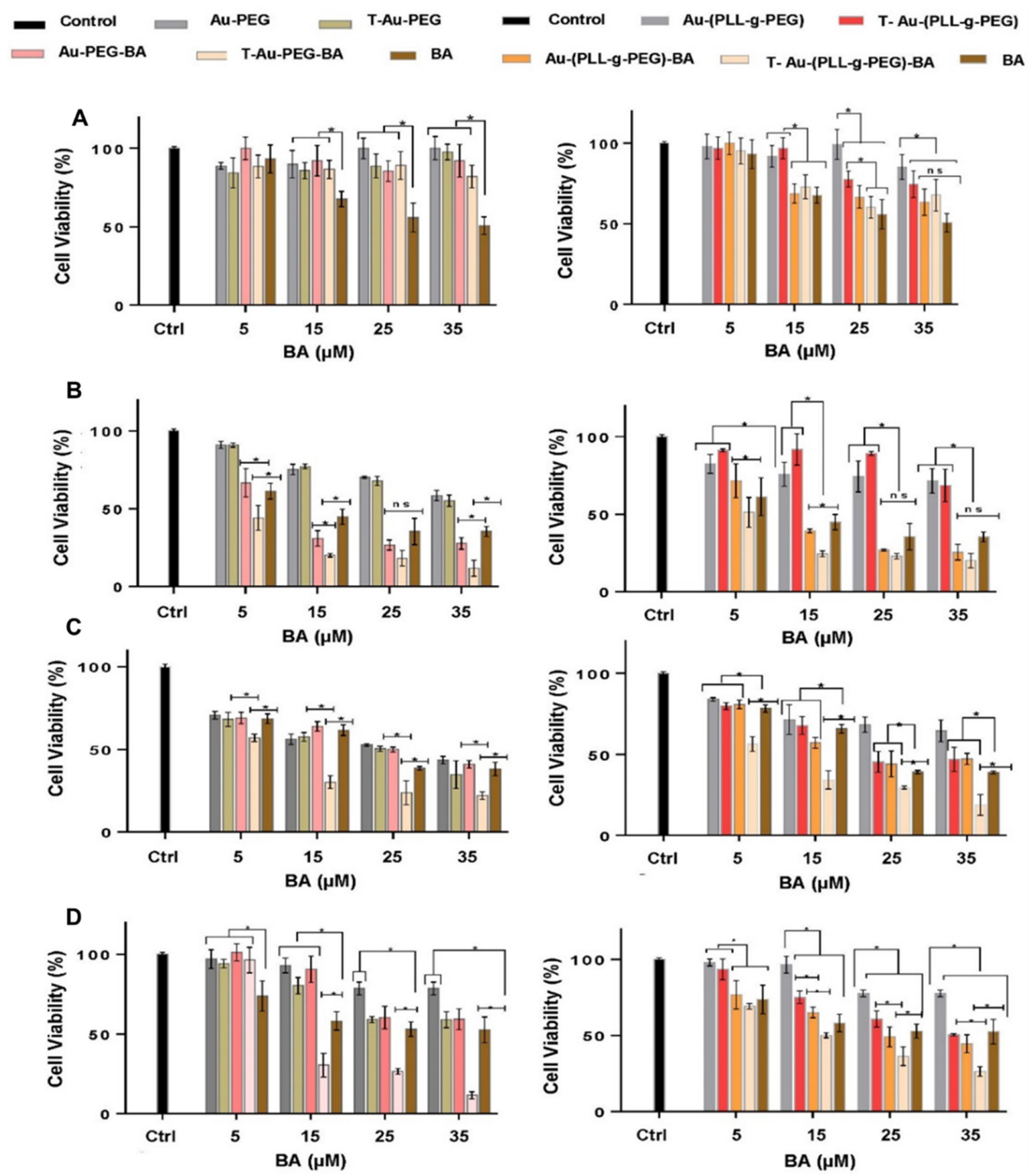

Figure 7. Effect of nanoparticles and drug nanocomplexes on cell viability in (A) HEK 293, (B) Caco-2, (C) HeLa and (D) MCF-7 cells. Au-PEG-BA; Au-[PLL-g-PEG]-BA = untargeted nanocomplexes, T-AuPEG-BA; T-Au-[PLL-g-PEG]-BA = targeted nanocomplexes, and BA= free drug. Data is represented as mean $\left.\pm \mathrm{SD}(n=3) ;{ }^{*} p<0.05\right) ; \mathrm{ns}=$ no significant difference. 
Table 2. Estimated $\mathrm{IC}_{50}$ values of $\mathrm{BA}$, targeted and untargeted nanocomplexes.

\begin{tabular}{cccccc}
\hline & Au-PEG-BA & T-Au-PEG-BA & Au-[PLL-g-PEG]-BA & T-Au-[PLL-g-PEG]-BA & BA \\
\hline \multicolumn{5}{c}{ Estimated IC $_{50}$ Values $(\mu \mathrm{M})$} \\
Caco-2 & 8.20 & 3.13 & 5.72 & 3.12 & 9.74 \\
HeLa & 25.37 & 6.51 & 23.64 & 3.26 & 17.73 \\
MCF-7 & 53.74 & 13.2 & 22.25 & 13.13 & 36.31 \\
\hline
\end{tabular}

\subsection{Effect on Mitochondrial Membrane Potential}

To elucidate the impact of targeted nanocomplexes on the mitochondria and their underlying mechanism of action, the effects of all nanocomplexes and free drug on the mitochondria in the three cancer cell lines was investigated. Due to their efficient mitochondrial localization, the targeted nanocomplexes, T-Au-PEG-BA and T-Au-[PLL-g-PEG]-BA showed significant impact on mitochondrial membrane potential compared to the untargeted and free BA (Figures 8 and 9).
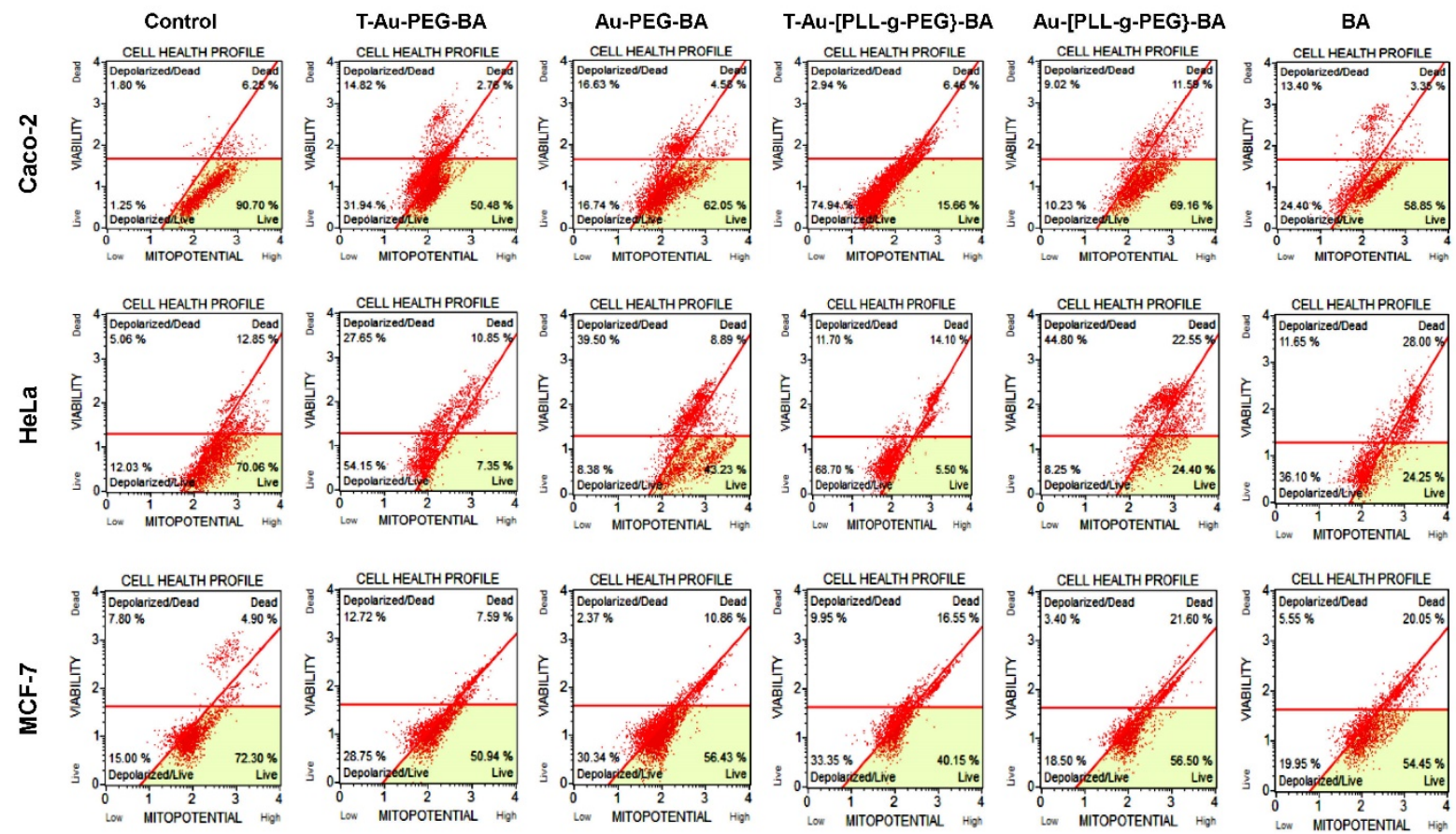

Figure 8. Cytographs of the effect of the targeted and untargeted nanocomplexes on the mitochondrial membrane potential in Caco-2, HeLa and MCF-7 cells. Au-PEG-BA; Au-[PLL-g-PEG]-BA = untargeted nanocomplexes, T-Au-PEG-BA; TAu-[PLL-g-PEG]-BA = targeted nanocomplexes, and BA = free drug. Top left quadrat: cell death by mitochondrial depolarization; top right quadrat: non-mitochondria dependent cell death; lower left quadrat: mitochondrial depolarization in live cells; lower right quadrat: live cells.

Results suggest a significant impact by the cationic T-Au-[PLL-g-PEG]-BA recording $74.94 \%, 68.7 \%$ and $33.35 \%$ depolarization in the Caco-2, HeLa and MCF-7 cell lines, compared to the $31.94 \%, 54.15 \%$ and $28.75 \%$ observed for T-Au-PEG-BA. Furthermore, the activity of the nanocomplexes in the MCF-7 cells was generally lower in comparison with their activity in the other cells, highlighting the selective sensitivity of BA to certain cancers and confirming previous reports $[10,35]$. 

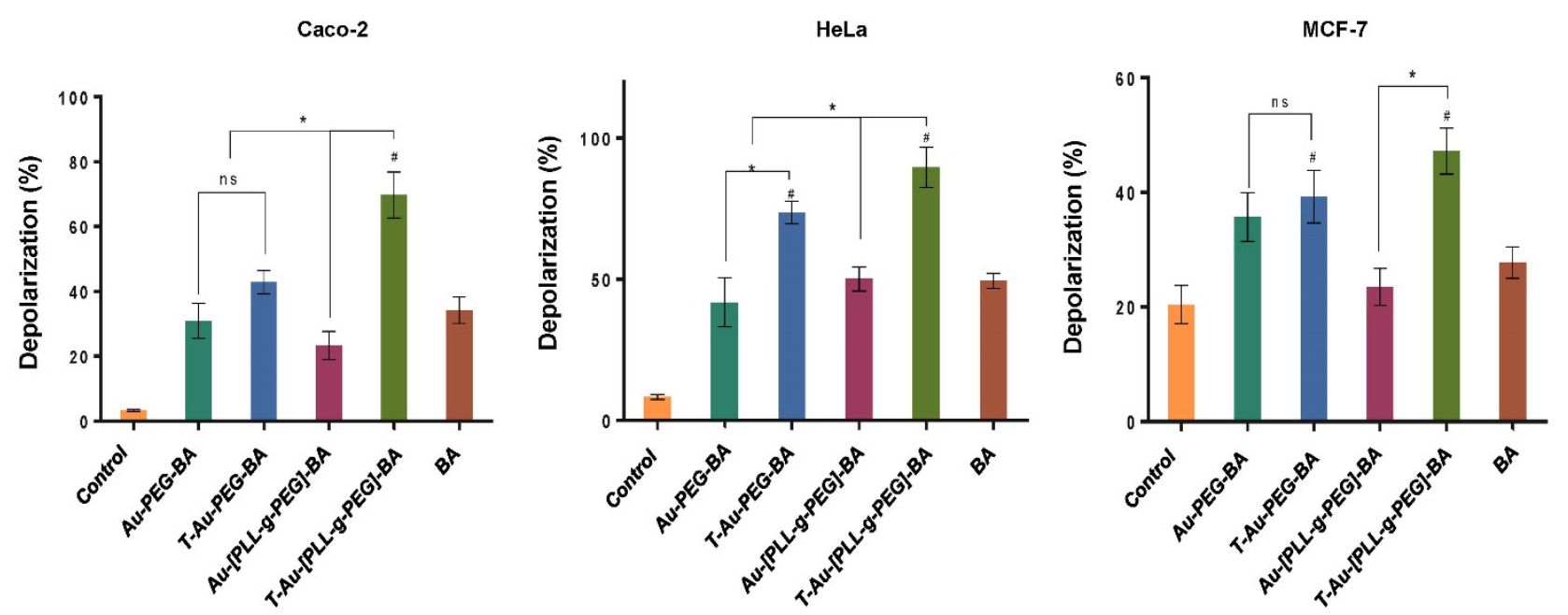

Figure 9. Graphical representation of the effect of targeted and untargeted nanocomplexes on the mitochondrial membrane potential in Caco-2, HeLa and MCF-7 cells. Data is represented as mean \pm SD $(n=3)$. * vs targeted or untargeted nanocomplex, \# vs. free drug at $p<0.05)$. ns = no significant difference.

\subsection{Impact on Caspases 3 and 7 Activity}

The activity of caspases 3 and 7 (Figures 10 and 11) were assessed as markers of apoptosis initiation, using a fluorescent substrate-DEVD of the executioner proteases, and the cell death marker 7-AAD. From Figures 10 and 11 it can be observed that the highest levels of activation were recorded by T-Au-[PLL-g-PEG]-BA in all three cells, with a total of $52.81 \%, 67 \%$ and $32.84 \%$ apoptotic cell populations compared to the $35.71 \%$, $49.95 \%$ and $24.25 \%$ for T-Au-PEG-BA, which is in tandem with results from the mitochondrial membrane potential dissipation. Apart from the demonstrated efficacy of the targeted nanocomplexes, they also demonstrated appreciable improvement over free BA in caspase induction.

\subsection{The Effect of Targeted Nanocomplexes on Apoptosis Induction}

Following incubation with the nanocomplexes and drug at predetermined concentrations, cells were stained with the AO/EB dual stain [28], to determine the extent of apoptosis in vitro. Fluorescent images showing cytomorphological changes indicative of apoptosis were noticed for treated cancer cell lines at varying degrees (Figure 12).

In comparison to the control cells (nontreated), morphological changes such as cell shrinkage and membrane blebbing indicative of apoptosis were observed in treated cells. These changes were moderate in BA treated cells, but generally severe in cells exposed to nanocomplexes. The dual staining technique is able to distinguish between early apoptotic cells, from cells at the final stage of apoptosis, with light yellow fluorescence indicating early apoptosis, and orange fluorescence suggesting cells are in the late stage of apoptosis. Overall, both targeted nanocomplexes showed significant improvement over free BA, demonstrating the importance of these NPs to enhance drug bioavailability and improve pharmacokinetics.

\subsection{The Impact of Targeted Nanocomplexes on Cell Cycle Progression}

The targeted nanocomplexes were then studied further to determine their impact on the cell cycle. Cells were incubated with an equimolar concentration of the drug and the nanocomplexes were assessed for distribution across the G0/G1, S and G2/M phases. There was appreciable cell distribution across the $S$ and G2/M phases in the control group for the Caco-2, HeLa and MCF-7 cells, compared to the treated groups (Figure 13), which is indicative of the high rate of proliferation in this group of cells. 

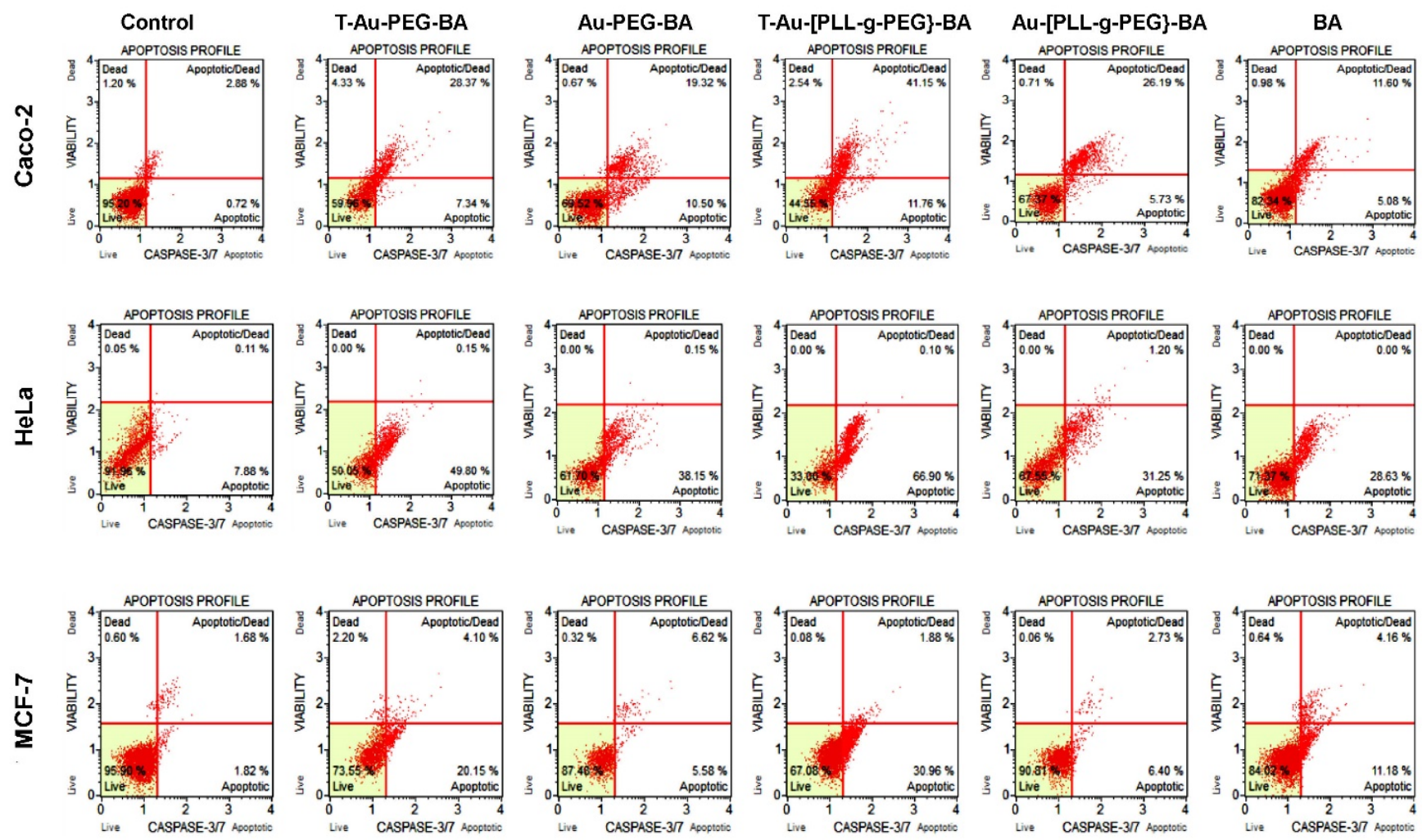

Figure 10. Cytographs showing the effect of targeted and untargeted nanocomplexes on caspases 3 and 7 in Caco-2, HeLa and MCF-7 cells. Au-PEG-BA; Au-[PLL-g-PEG]-BA = untargeted n nanocomplexes, T-Au-PEG-BA; T-Au-[PLL-g-PEG]-BA = targeted nanocomplexes, and BA = free drug. Top left quadrat: cell death by non-apoptotic mechanisms; top right quadrat: cell death by caspase dependent apoptosis; lower left quadrat: Live cells; lower right quadrat: cells undergoing caspase dependent apoptosis.
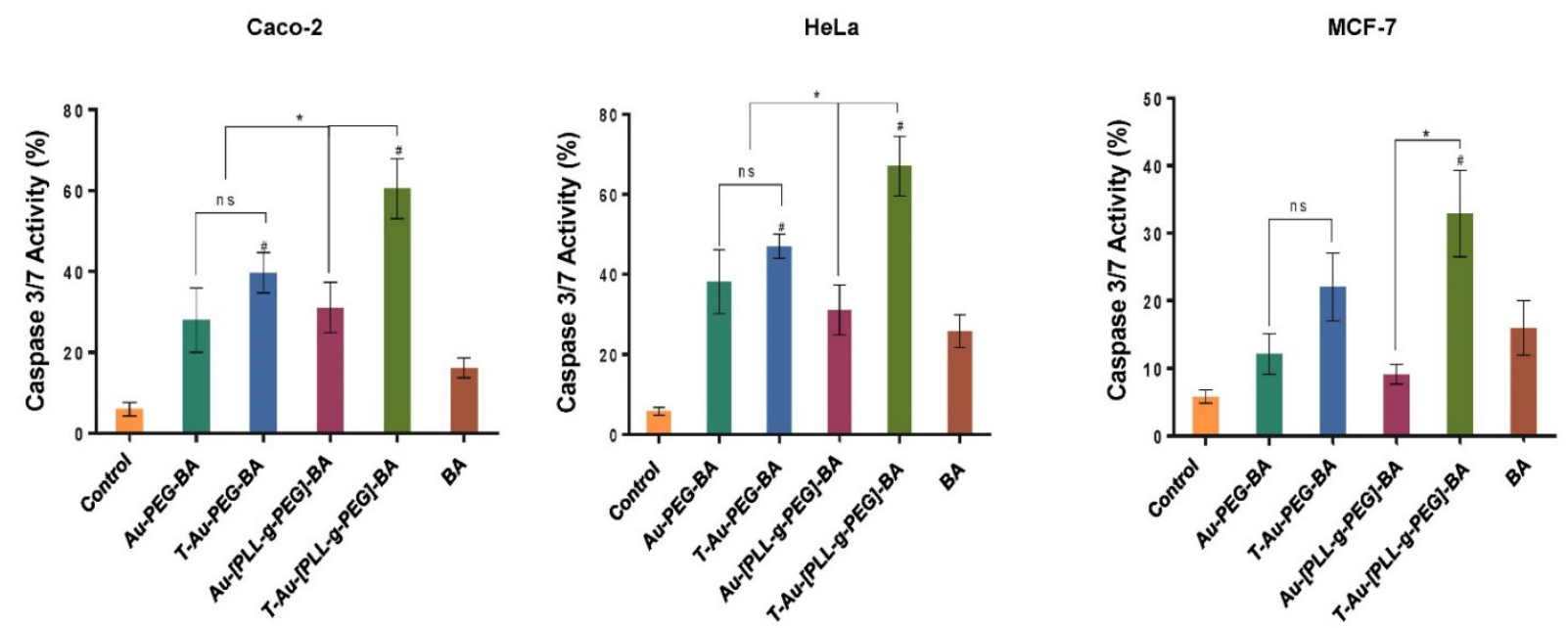

Figure 11. Graphical representation of the effect of targeted and untargeted nanocomplexes on caspases 3 and 7 in Caco-2, HeLa and MCF-7 cells. Data is represented as mean $\pm \mathrm{SD}(n=3) .{ }^{*}$ vs. targeted or untargeted nanocomplex, \# vs. free drug at $p<0.05$. $\mathrm{ns}=$ no significant difference. 

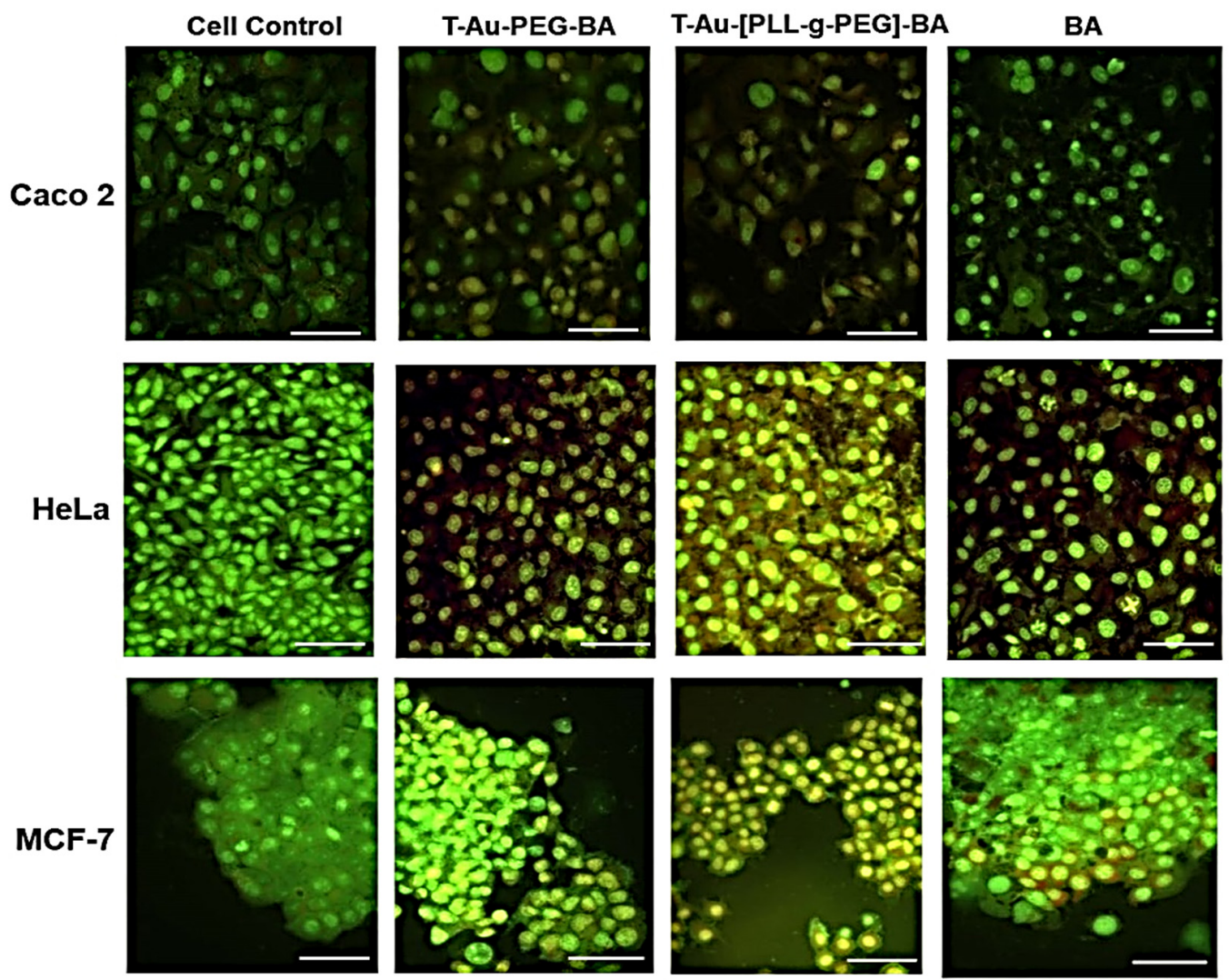

Figure 12. Sectional fluorescent images of acridine orange/ethidium bromide stained cells showing apoptosis induction by targeted nanocomplexes. T-Au-PEG-BA; T-Au-[PLL-g-PEG]-BA = targeted nanocomplexes, and BA = free drug. Untreated cells and BA served as controls. Scale bar $=100 \mu \mathrm{m}$.

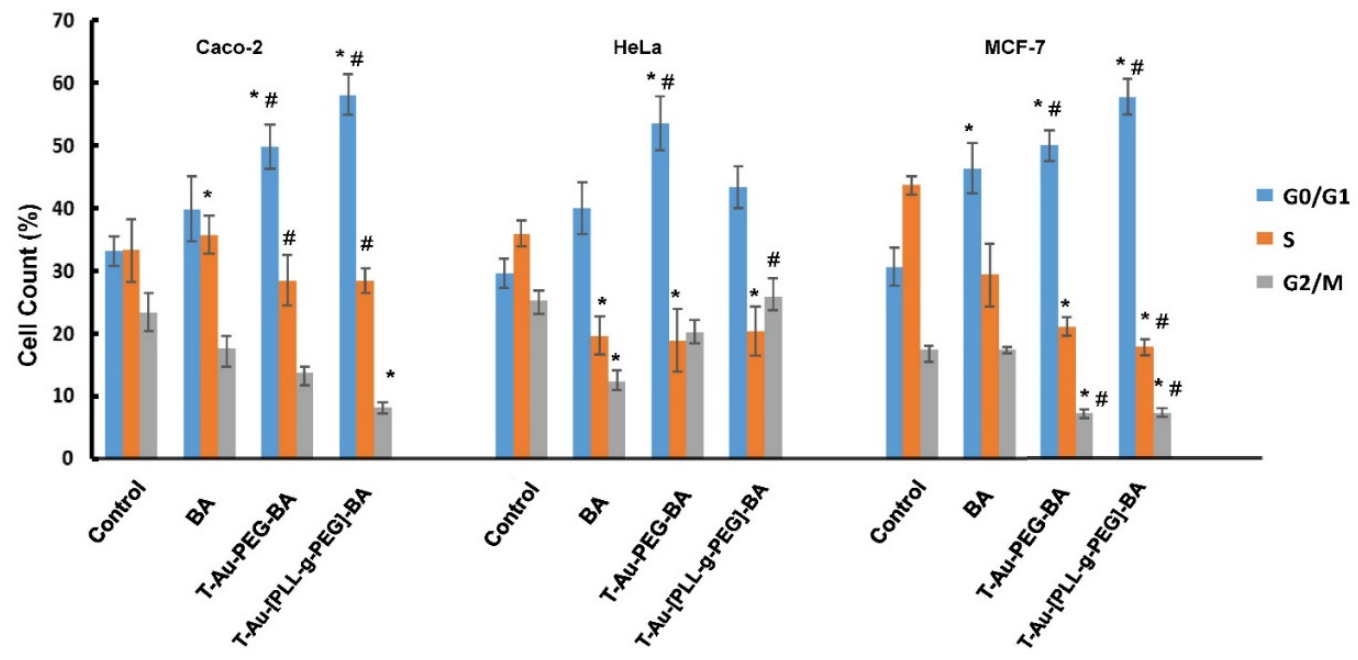

Figure 13. Graphical representation showing the effect of T-Au-PEG-BA, T-Au-[PLL-g-PEG]-BA and BA on cell cycle progression. T-Au-PEG-BA; T-Au-[PLL-g-PEG]-BA = targeted nanocomplexes, and $\mathrm{BA}=$ free drug. Data is represented as mean $\pm \mathrm{SD}(n=3) .{ }^{*}$ vs. control, \# vs. free drug at ${ }^{*} p<0.05$.

Upon addition of the various treatments, a comparable decrease in cell population for the two phases was noticed, with a corresponding increase in cell number at the G0/G1 phase. In the Caco-2 cells, a significant increase in the number of cells arrested at the G0/G1 phase was observed for T-Au-[PLL-g-PEG], recording a 1.8-fold increase over the control. T-Au-PEG-BA and BA also recorded increases. In the MCF-7 cells, the trend was similar, 
with the G0/G1 cell population increasing from $30 \%$ in the control to $46 \%, 57 \%$, and $66 \%$ in BA, T-Au-PEG-BA, and T-Au-[PLL-g-PEG], respectively. However, in the HeLa cells, the highest G0/G1 arrest was observed for T-Au-PEG-BA, recording a 1.83-fold increase compared to that for T-Au-[PLL-g-PEG] (1.48-fold), further demonstrating the efficacy of the targeted nanocomplexes over the free drug.

Figure 14 provides an illustration depicting the cellular uptake, mitochondrial localization and mechanisms involved in cell death.

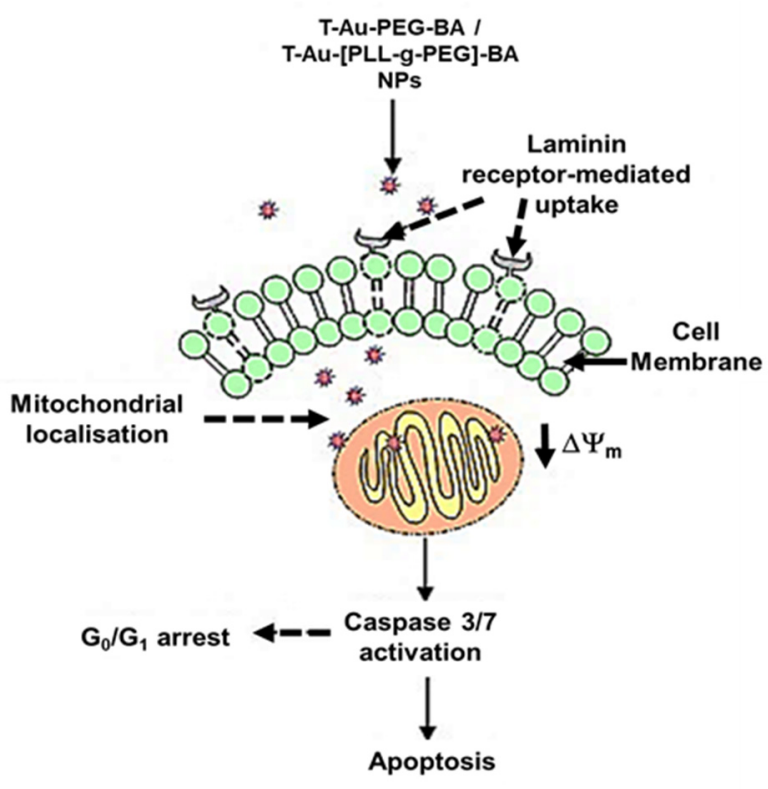

Figure 14. Illustration indicating possible mechanisms involved in cell death.

\section{Discussion}

The identification of the mitochondria as a therapeutic target for cancer chemotherapy initiated the search for therapeutics capable of impacting mitochondrial integrity and inducing apoptosis in cancer cells. Although studies have identified other cytoplasmic targets for BA, the merit for preferentially targeting the mitochondria lies in the high susceptibility of cancer mitochondria to mito-active agents owing to their dysfunctional status, thereby making the approach more specific as the impact on noncancer cells is generally negligible [36-38]. Therefore, for efficacy and specificity, the targeted delivery of mitochondrial-active principles has become an emerging area of research.

The organic synthesis of NPs which has seen increasing application in clinical research has shown significantly low environmental toxicity and ease of synthesis. AuNPs were successfully synthesized by exploiting the strong redox properties of the green tea polyphenol, EGCG to reduce the gold chloride. The EGCG-capped AuNPs were further functionalized with PLL and PEG to produce EGCG-capped laminin receptor-avid AuNPs for drug delivery to the mitochondria. The functionalization of NPs with polymers has been reported to improve NP stability, reduce agglomeration, allow for conjugation of bioactive moieties, and importantly, forestall NP immunogenicity while improving stealth properties in vivo $[7,39,40]$. The covalent attachment of PLL to AuNPs via its amide group has been reported to provide the gold-based nano-delivery system with favorable properties for gene delivery. The many active amino groups of PLL can accept protons at acidic $\mathrm{pH}$ and have been observed to significantly promote cell adhesion [41]. The amount of PEG in the formulation was sufficient to promote stabilization and produce NPs and nanocomplexes smaller than $150 \mathrm{~nm}$. Higher densities of PEG may cause the PEG chains to extend further from the NP forming a brush border [42,43]. This may impact on the interaction between the NP and the cells. 
The successful synthesis and functionalization of the NPs was confirmed by UV-vis spectroscopy, FTIR and ${ }^{1} \mathrm{H}$ NMR (Supplementary Materials Figures S1-S3), with NPs and nanocomplexes exhibiting varying color intensities. The magnitude of absorption and wavelength shifts observed from the UV spectra indicate changes in nanoparticle size and stability upon functionalization, due to its impact on the charge density and oscillation of electrons on NP surface. The presence of the AuNPs was confirmed by an excitation peak at $524 \mathrm{~nm}$, while evidence for functionalization with PEG and PLL, and BA encapsulation were observed as red or blueshifts in the SPR, corresponding to a reduction or increase in NP size, respectively. It has been reported that modification of the surface of AuNPs is often denoted by a significant reduction in the absorption intensity in addition to marginal peak shifts [28], with the broadening of a peak suggesting NP aggregation due to low stability [44]. Upon PEG conjugation, a minimal blueshift in peak wavelength from 524 to $522 \mathrm{~nm}$ was observed, reflecting a change in the surface property of the NP, as reported previously [45]. $\mathrm{TPP}^{+}$and BA conjugation resulted in a redshift to $542 \mathrm{~nm}$, indicating a size increase, with the broadening of peaks and reduced intensity suggesting a tendency for agglomeration, especially for the T-Au-PEG-BA nanocomplexes. Although T-Au-PEG-BA had high a zeta potential (Table 2), indicating strong stabilizing repulsive forces between the colloidal particles, a mild to severe agglomeration has been associated with increasing ionic strength of NP suspensions in spite of high zeta potential values. It is suspected that an increase in ionic strength upon addition of $\mathrm{TPP}^{+}$to Au-PEG may have impacted on the stability of T-Au-PEG-BA. In contrast, PLL-g-PEG coated NPs demonstrated significant stability, with the redshifts indicating changes in surface properties and size increase. This observed stability may be a combination of its high zeta potential (Table 1), the steric stabilization conferred by PEG, and the high density of positively charged amines on the NP surface which prevented aggregation. Furthermore, T-Au-[PLL-g-PEG]-BA (533 nm) produced a sharp peak and a blueshift compared to T-Au-[PLL-g-PEG] $(541 \mathrm{~nm})$ and $\mathrm{Au}$-[PLL-g-PEG] (534 nm) indicating better stability.

For drug loading, BA was coupled to the NP's surface by Steglich esterification between the hydroxyl groups on the NP and the carboxylic groups of BA. Although, the functionalized NPs recorded low $(<25 \%)$ loading efficiency which was lower than that for porous NPs with efficiencies $>50 \%$, the values recorded are higher than the $10 \%$ benchmark for ideal nanocarriers [46]. It has been suggested that significant therapeutic effects are achievable at lower drug concentrations for subcellular targets such as the mitochondria, with drug release proposed to involve the action of mitochondrial proteases [47]. NP size, surface charge and shape influence their delivery potential, distribution, clearance, accumulation at intended sites via enhanced permeability retention (EPR) and cellular and organellar interactions [48]. TEM revealed small spherical particles which were dark and dense due to the great light scattering properties of gold. As expected, the size of the NPs using TEM were in contrast with that of the hydrodynamic analysis (NTA) which determines the properties of NPs in an aqueous medium which could have resulted in some swelling of the NPs. NTA is a robust technique that provides the size, dispersity and colloidal stability of a NP in real time, by using laser light scattering to track individual particles based on their Brownian motion [2]. The hydrodynamic diameter, also referred to as the Stokes diameter, takes into consideration the presence of a hydration layer around the NP, and is also dependent on the diameter of the NP corona. The initial hydrodynamic diameter of the AuNPs resulted in size changes upon functionalization, which was not very clear from the TEM images. It has been reported that NPs of the sizes $<200 \mathrm{~nm}$ have good interaction with the cellular membrane and are readily taken up via clathrin-mediated endocytosis [49,50]. All nanocomplexes in this study were favorably under $150 \mathrm{~nm}$ in size. Such small sizes are significant in drug delivery, since these drug nanocarriers can easily escape the leaky tumor vasculature to accumulate at the tumor site and induce their anticancer effects [2].

Zeta potential has become a powerful tool for examining the electrostatic forces within the bulk solution and on the surface of the NPs and nanocomplexes [51]. It is de-fined as 
the magnitude of the electrostatic potential generated on the edge of the slipping plane between the particle and the dispersant medium. The NP interacts with the ions in the dispersant medium $[52,53]$. The zeta potential is a good measure of NP stability, with values of $\pm 20 \mathrm{mV}$ irrespective of charge being regarded as highly stable. It can also inform on the net surface charge of a NP [54]. When zeta potentials are $<-15$ or $>+15 \mathrm{mV}$, the attractive forces exceed the repulsive forces resulting in NP aggregation [2]. This was evident for Au-[PLL-g-PEG]-BA which had a low zeta potential $(11.8 \mathrm{mV})$ in addition to being larger $(147.4 \mathrm{~nm})$ than the other nanocomplexes. Hence, these nanocomplexes had the tendency to aggregate which could account for the large size recorded. T-Au-PEG and T-Au-[PLL-g-PEG] recorded high zeta potential values of -23.1 and $+23.4 \mathrm{mV}$, respectively, suggesting stability and low tendency for agglomeration. Since NPs with positive zeta potentials are assumed to interact favorably with anionic cell membranes, it is also possible for NPs with negative zeta potential to enter cells and induce their therapeutic activity [53]. The polydispersity index (PDI) provides us with an indication of the uniformity of a particle size in solution. The larger the PDI value, the larger the size distribution in the sample. The PDI value can also provide an insight into particle aggregation, consistency and the efficiency of the modifications on the NP. Generally, monodisperse samples have PDI values less than 0.1 [32], moderately dispersed samples have PDI values between 0.1 and 0.4 , and PDI values $>0.4$ have a broad size distribution [40]. Hence, the formulated NPs and nanocomplexes were close to homogeneity with only Au-PEG-BA being moderately dispersed. Importantly, the functionalization of the AuNPs did not greatly affect their dispersity in solution.

Charged NPs generally are capable of indiscriminate interaction with biomolecules, nevertheless, cationic NPs readily associate with the cellular membrane and enjoy significant cellular uptake by cells compared to anionic NPs. The uptake of NPs into cancer cells is mediated via three classical pathways, the clathrin mediated pathway, caveolae dependent endocytosis and macropinocytosis. However, the route of uptake is determined by the size, shape and surface charge of the NPs. Cellular targeting using receptor agonists as the homing moiety for NPs help improve uptake, allows for cell-specific delivery, and precludes toxicity to normal cells [55]. The avidity of the nanocomplexes to the laminin receptor in the presence of the laminin receptor-specific Laminin- $\mathrm{R}$ antibody $(\mathrm{H}-2)$, suggested that cellular uptake was largely receptor-dependent, with both targeted nanocomplexes recording a marked reduction in uptake in the presence of the antibody. Although cationic NPs are expected to easily cross the cell membrane due to the negative membrane potential across the bilayer, the lower count observed for the T-Au-[PLL-g-PEG] NPs in spite of its cationic nature may be due to its larger size (147 nm compared to the $98 \mathrm{~nm}$ of T-Au-PEG).

The high negative membrane potential $(-180 \mathrm{mV})$ perpetuated by oxidative phosphorylation restricts the movement of negatively charged particles into the inner mitochondrial membrane. In its hyperpolarized state, as in cancers, mitochondrial membrane potential may increase to as high as $-210 \mathrm{mV}$, encouraging a high amplitude translocation of cationic molecules across the inner membrane. This is one of the factors responsible for the higher susceptibility of cancer mitochondria to mitochondriotropic agents compared to those of noncancer cells. T-Au-[PLL-g-PEG] due to its highly cationic nature, showed the highest mitochondrial localization compared to Au-[PLL-g-PEG], T-Au-PEG and Au-PEG in all three cell lines. Although, T-Au-PEG also demonstrated appreciable mitochondrial localization, its lower mitochondrial accumulation compared to T-Au-[PLL-g-PEG] in spite of a high cellular uptake, may have been influenced by its negative surface charge hampering its interaction with the hyperpolarized mitochondrial membrane. Studies on the relationship between NP size and mitochondrial uptake reported optimum uptake at a particle size between 80 and $100 \mathrm{~nm}$, with a gradual decline till about $210 \mathrm{~nm}$, after which uptake is negligible [47].

The observed tolerance of NPs and drug loaded nanocomplexes in the noncancer HEK293 cells, compared to the toxicity of the free BA affirms their biocompatibility and potential to prevent cargo-associated toxicity in normal cells. Their negligible impact on 
HEK293 cell viability may be associated with their high affinity for the laminin receptor, which is not overexpressed in these cells as in cancer cells, in addition to the normal functional state of the mitochondria in the HEK293 cells. In the cancer cells, drug-loaded nanocomplexes showed significant cytotoxicity compared to the free drug across all concentrations. T-Au-PEG-BA and T-Au[PLL-g-PEG]-BA displayed a concentration dependent inhibition of cell growth in all three cancer cell lines. Cancer cell mitochondria are dysfunctional and significantly hyperpolarized, enhancing the mitochondrial accumulation of cationic or mitochondrial targeted NPs and their cargo [47,56]. This explained their high susceptibility to T-Au-PEG-BA and T-Au[PLL-g-PEG]-BA treatments. Some studies have reported that negatively charged NPs do not readily translocate into the mitochondria due to their high negative membrane potential, while other studies have established the affinity of EGCG to the mitochondria [49,57]. A 90-95\% accumulation of radioactive ${ }^{3} \mathrm{Au}-\mathrm{EGCG}$ in the mitochondria of primary cultures of rat cerebellar granule neurons was reported [58]. Hence, T-Au-PEG-BA in spite of its negative surface charge may have been influenced by the EGCG component of the nanocomplex. Overall, the lower impact of free BA on the viability of the cancer cells compared to that of the targeted nanocomplexes emphasizes the challenge of poor pharmacokinetics in chemotherapy, while demonstrating the importance of specialized nanodelivery platforms such as T-Au-PEG and T-Au[PLL-g-PEG] in mitigating this challenge.

Tumors are reliant on anerobic respiration for energy generation, and mitochondrial membrane hyperpolarization is a consequent anomaly arising from the accumulation of the proton motive force across the inner mitochondria membrane. The dissipation of this membrane potential compromises the mitochondrial membrane integrity, setting-off a cascade of events leading to cell death [59]. While its antiproliferative effect has been linked to a host of mechanisms, the impact of BA on the modulation of apoptotic signaling, the consequent opening of the mitochondria membrane permeability transition pore through ROS generation, and the release of cytochrome $\mathrm{c}$ has been established $[13,60]$. The assessment of the impact of free BA, and the nanocomplexes on mitochondrial membrane potential revealed highly significant membrane depolarizations by T-Au-PEG-BA and T-Au[PLL-g-PEG]-BA compared to the untargeted (Au-PEG-BA and Au-[PLL-g-PEG]-BA), and free BA, highlighting the efficacy of this targeted approach. Moreover, T-Au-[PLL-gPEG]-BA showed higher depolarization of the cancer cells, compared to T-Au-PEG-BA. Considering the cytotoxicity initially recorded for T-Au-PEG-BA, and its low impact on the mitochondrial membrane potential, attests to the possibility of other cytoplasmic targets, and the induction of non-mitochondrial dependent auxiliary pathways of cell death, as reported by other investigators [60-63].

The cascade of events following the loss of mitochondrial membrane potential due to mitochondrial membrane disruption includes the release of cytochrome $\mathrm{c}$ from its intermembrane stores and the activation of initiator caspases, and the subsequent activation of executioner caspases such as caspases 3 and 7. A similar trend to that of the membrane potential analysis was noted, with targeted constructs eliciting the highest percentage of caspase 3/7-mediated cell death compared to both the untargeted and free BA treatments. Overall, T-Au-[PLL-g-PEG]-BA demonstrated a higher efficacy compared to T-Au-PEG-BA, corroborating earlier inference that the comparable cytotoxic effect of T-Au-PEG-BA is likely connected to its impact on other cytoplasmic targets as influenced by its higher cellular uptake and lower mitochondrial localization. Hence, the apparent effectiveness of T-Au-[PLL-g-PEG]-BA may be linked to its superior mitochondria targeting potential as demonstrated in the localization study. These findings further emphasize the potential of efficient mitochondrial targeting platforms, especially, T-Au-[PLL-g-PEG] to enhance drug pharmacokinetics. The significant apoptogenic potential of T-Au-[PLL-g-PEG]-BA was again confirmed by fluorescent apoptotic studies employing the AO/EB dual stain.

Studies have established a relationship between cell cycle arrest and caspase dependent apoptosis $[64,65]$. The upregulation of the p53 protein, its downstream effector, p21, and the downregulation of cyclins D and E, and an arrest at the G1 phase of the cell cycle 
are some of the consequent highlights of apoptosis induction [66]. The effect of the targeted nanocomplexes on the cell cycle revealed arrests at the G0/G1 phase compared to the control in all the cells, with T-Au-[PLL-g-PEG]-BA having a significant impact in the Caco-2 and MCF-7 cells, compared to the control, free BA and T-Au-PEG-BA. These findings are in consonance with earlier reports on the effect of BA-rich Dillenia suffruticosa root extracts in MCF-7 cells and as well as free BA in oral squamous cell cancer $[67,68]$.

\section{Materials and Methods}

\subsection{Materials}

Tetrachloroaurate (III) trihydrate $\left(\mathrm{HAuCl}_{4}-3 \mathrm{H}_{2} \mathrm{O}\right)$, poly-L-lysine hydrobromide (PLL, Mw 1000-4000), (-)-epigallocatechin gallate (EGCG), N-hydroxysuccinimide (NHS), betulinic acid, $\mathrm{N}$-(3-dimethyl aminopropyl)-N'-ethyl carbodiimide hydrochloride (EDC), 4-(dimethylamino)pyridine (DMAP), (4-Carboxybutyl)triphenyl-phosphonium bromide, dialysis tubing (MWCO 2000) and the bicinchoninic acid (BCA) assay kit were obtained from Sigma-Aldrich, St. Louis, MO, USA. Polyethyleneglycol 2000 (Mw 1800), acridine orange, ethidium bromide, and 3-(4-,5-dimethylthiazol-2-yl)-2,5-diphenyltetrazolium bromide (MTT) were supplied by Merck, Darmstadt, Germany, while cell lysis buffer (5x) was purchased from Promega Corporation, Madison, USA. The Muse ${ }^{\circledR}$ cell cycle, caspase and mitopotential kits were sourced from Luminex Corporation, Austin, TX, USA All other reagents were locally purchased and of analytical grade. The human embryonic kidney (HEK293), colorectal adenocarcinoma (Caco-2), breast adenocarcinoma (MCF-7), and cervical adenocarcinoma (HeLa) cell lines were initially procured from the American Type Culture Collection (ATCC), Manassas, VA, USA. Minimum essential medium (EMEM), trypsin-versene and penicillin/streptomycin $(10,000 \mathrm{U} / \mathrm{mL}$ penicillin, 10,000 U/mL streptomycin) were obtained from Lonza Bio Whittaker, Verviers, Belgium. Fetal bovine serum (FBS) was supplied by Hyclone, GE Healthcare, Utah, USA. All sterile tissue culture grade plasticware were obtained from Corning Inc. (New York, NY, USA). Cell culture medium was supplemented with $10 \% \mathrm{FBS}$ and 1\% penicillin/streptomycin amphotericin B mixture, and incubated at $37^{\circ} \mathrm{C}$ in $5 \% \mathrm{CO} 2$.

\subsection{Synthesis of EGCG Capped AuNPs}

We synthesized EGCG-capped AuNPs by the reduction of hydrogen tetrachloroaurate (III) trihydrate ( $\left.\mathrm{HAuCl}_{4}-3 \mathrm{H} 2 \mathrm{O}\right)$ with EGCG as previously described [21,40]. Briefly, $100 \mu \mathrm{L}$ of $0.3 \mathrm{mM} \mathrm{HAuCl} 4-3 \mathrm{H} 2 \mathrm{O}$ was added to a $10 \mathrm{~mL}$ stirring $0.11 \mathrm{mM}$ solution of EGCG in water. The mixture was stirred for an additional $10 \mathrm{~min}$ to allow for complete AuNP formation. Thereafter, the suspension was purified by dialysis (MWCO $2000 \mathrm{Da}$ ) against ultrapure water over $12 \mathrm{~h}$. The formation of EGCG capped AuNPs was confirmed by UV spectroscopy.

\subsection{Synthesis of AuNP-BA}

BA was loaded into the EGCG capped AuNPs by Steglich esterification involving the carboxylic group of BA and the hydroxyl groups of EGCG [69]. BA (0.5 mM) and 4-dimethylaminopyridine $(0.4 \mathrm{mM})$ were dissolved in $2 \mathrm{~mL}$ deionized water and stirred for $1 \mathrm{~h}$. The mixture was then added with stirring to the AuNP suspension in a 1:5 final ratio $(v / v)$. Thereafter, EDC $(0.134 \mathrm{~g}, 0.7 \mathrm{mM}$ in $2 \mathrm{~mL}$ deionized water) was added dropwise to the mixture, which was stirred overnight at room temperature for the reaction to proceed. The AuNP-BAs were purified by dialysis as in Section 4.2.

\subsection{Synthesis of Poly-L-Lysine-Graft-(g)-Polyethylene Glycol Copolymer (PLL-g-PEG)}

PEG-imidazole (PEG-CI) was first synthesized. Approximately, $0.2 \mathrm{~g}$ of 1, 1'-carbonyl diimidazole (CDI) was dissolved in $10 \mathrm{~mL}$ dioxane and added to a $0.1 \mathrm{~g}$ dry PEG solution in $25 \mathrm{~mL}$ of toluene. The mixture was stirred overnight at $50{ }^{\circ} \mathrm{C}$ and concentrated by rotary evaporation. The resultant yellow liquid was diluted with $50 \mathrm{~mL}$ dichloromethane and transferred to an ice bath where $20 \mathrm{~mL}$ of $1 \mathrm{M} \mathrm{NaCl}$ was added while stirring until 
effervescence ceased. The organic layer was then separated from the cloudy aqueous layer, washed twice with water and dried for $12 \mathrm{~h}$ with anhydrous $\mathrm{Na}_{2} \mathrm{SO}_{4}$. The $\mathrm{Na}_{2} \mathrm{SO}_{4}$ was then filtered and the filtrate concentrated and lyophilized. 1H NMR $\left(600 \mathrm{MHz}, \mathrm{CDCl}_{3}\right)$ $\delta 8.88,8.11,7.49,7.30,7.29,3.75,3.74,3.74,3.68,3.68,3.67,3.66,3.66,3.63,3.63,2.97$ (Supplementary Materials Figure S1).

Poly-L-lysine (PLL, $5 \mathrm{mg}$ ) was dissolved in freshly prepared sodium borate buffer (pH 9), followed by the addition of $20 \mathrm{mg}$ of PEG-CI (based on the $82 \%$ yield) and stirred overnight. The solution was then dialyzed as in Section 4.2, concentrated and lyophilized. ${ }^{1} \mathrm{H}$ NMR (400 MHz, $\left.\mathrm{D}_{2} \mathrm{O}\right) \delta 4.70,4.23,4.14,3.62,3.01,2.86,1.81,1.58,1.29$ (Supplementary Materials Figure S2).

\subsection{Synthesis of Triphenylphosphine-PLL-g-PEG (T-PLL-g-PEG)}

The synthesis of T-PLL-g-PEG was accomplished by amide coupling between the free carboxylic end of (4-carboxybutyl) triphenyl-phosphonium bromide (TPP- $\left.\left(\mathrm{CH}_{2}\right)_{4}-\mathrm{COOH}\right)$ and the free amino groups of PLL. TPP- $\left(\mathrm{CH}_{2}\right)_{4}-\mathrm{COOH}(0.1 \mathrm{~g}, 0.226 \mathrm{mM})$, NHS $(0.04 \mathrm{~g}$, $0.339 \mathrm{mM})$ and EDC $(0.0433 \mathrm{~g}, 0.226 \mathrm{mM})$ were dissolved in $5 \mathrm{~mL}$ of water and stirred for $1 \mathrm{~h}$. To this was added PLL-g-PEG-OH $(10 \mathrm{mg} / \mathrm{mL})$ with stirring overnight at room temperature. The product was purified by dialysis as in Section 4.2 for $6 \mathrm{~h}$ and then concentrated and lyophilized. ${ }^{1} \mathrm{H}$ NMR (400 MHz, DMSO) $\delta 7.90,7.81,7.76,6.07,6.00,3.51$, $2.99,2.89,2.59,2.46,2.39,1.71,1.61,0.99$ (Supplementary Materials Figure S3).

\subsection{Synthesis of T-Au-[PLL-g-PEG]-BA), Au-PLL-g-PEG-BA, and T-Au-PEG-BA}

Lyophilized T-(PLL-g-PEG) was resuspended in ultrapure water $(2 \mathrm{mg} / \mathrm{mL})$ and added dropwise to a stirring AuNP-BA suspension in a 1:10 $(v / v)$ final ratio. The mixture was stirred for $6 \mathrm{~h}$, and thereafter dialyzed overnight against water to remove any unreacted T-(PLL-g-PEG). This procedure was repeated for formation of untargeted constructs using PLL-g-PEG. T-Au-PEG-BA NPs were synthesized by a sequential conjugation of PEG-CI and TPP- $\left(\mathrm{CH}_{2}\right)_{4}-\mathrm{COOH}$ to the $\mathrm{OH}$ groups on AuNP-BA. A PEG-CI solution $(10 \mathrm{mg} / \mathrm{mL})$ was added dropwise to a stirring AuNP-BA suspension ( $\mathrm{pH}$ 9). The reaction was allowed to proceed overnight, and thereafter dialyzed, as previously for $8 \mathrm{~h}$ to remove unreacted PEGCI. Thereafter, TPP- $\left(\mathrm{CH}_{2}\right)_{4}-\mathrm{COOH}(0.29 \mathrm{mM})$ and 4-dimethylaminopyridine $(0.29 \mathrm{mM})$ were dissolved in $2 \mathrm{~mL}$ deionized water and stirred for $1 \mathrm{~h}$. The mixture was then added to the AuNP-PEG-BA suspension in a 1:10 final ratio $(v / v)$ with stirring. Thereafter, EDC (0.29 $\mathrm{mM}$ in $1 \mathrm{~mL}$ deionized water) was added dropwise to the stirring mixture. The reaction was allowed to proceed overnight at room temperature and thereafter, the product was purified by dialysis as in Section 4.2.

\subsection{Drug Loading Efficiency}

A $2 \mathrm{~mL}$ aliquot of the NP-drug complex (nanocomplex) was degraded by using $1.0 \mathrm{mM}$ potassium iodide, and then centrifuged at $12,000 \times \mathrm{g}$ for $10 \mathrm{~min}$ to obtain a clear supernatant. The supernatant was subjected to UV-vis spectroscopy at $210 \mathrm{~nm}$, while the corresponding BA concentration was deduced from a standard curve. The procedure was repeated 5 times, and loading efficiency determined from the average by the Equation below:

$$
\text { Loading efficiency }(\%)=(\text { Encapsulated drug }) /(\text { Total drug added }) \times 100
$$

\subsection{Nanoparticle Characterization}

Changes in optical property and stability of the AuNPs upon synthesis and functionalization were monitored via UV-vis spectroscopy (Jasco V-730 Bio Spectrophotometer, JASCO Corporation, Hachioji City, Japan) over a wavelength range of 400-800 nm. Bond formation and functionalization of the AuNPs were determined by changes in absorption bands as evidenced by Fourier Transform Infra-red (FTIR) spectrometry (ATR-FTIR spectroscopy PerkinElmer, Inc. USA). NP shape, size and dispersity were determined from images generated by transmission electron microscopy (TEM) (JEM 1010, JEOL, Tokyo, 
Japan). Hydrodynamic diameters, zeta-potential and stability were measured by nanoparticle tracking analysis (NTA) (Nanosight NS500, Malvern, Worcestershire, UK), at $25^{\circ} \mathrm{C}$, and analyzed using the NTA version 3.2 software.

\subsection{Cell Culture}

All cell culture protocols were conducted under sterile conditions in an Airvolution Class II biosafety laminar flow hood (United Scientific, South Africa). Human colorectal adenocarcinoma (Caco-2), cervical carcinoma (HeLa), breast adenocarcinoma (MCF-7) and embryonic kidney (HEK293) cells were grown as adherent cultures at $37^{\circ} \mathrm{C}$ under $5 \% \mathrm{CO}_{2}$ (Steri-Cult $\mathrm{CO}_{2}$ incubator with class 100 HEPA filtration, Thermo Electron Corporation), in $25 \mathrm{~cm}^{2}$ culture flasks containing $5 \mathrm{~mL}$ of complete medium (EMEM supplemented with FBS $10 \%(v / v)$ and antibiotic $(100 \mathrm{U} / \mathrm{mL}$ penicillin, $100 \mu \mathrm{g} / \mathrm{mL}$ streptomycin, $0.25 \mu \mathrm{g} / \mathrm{mL}$ amphotericin B)). Medium was routinely renewed until cells reached confluency. Confluent cells were trypsinized and cryopreserved, or propagated to increase cells numbers, or seeded into multiwell plates for cell-based experiments. All cell-based experiments were conducted in triplicate.

\subsection{Cellular Uptake Studies}

Cellular uptake was undertaken in HeLa cells that were seeded in 48-well plates $\left(2.0 \times 10^{3}\right.$ cells $/$ well $)$ and incubated for $12 \mathrm{~h}$. Cells in selected wells were incubated with the Laminin $\mathrm{R}$ antibody $(\mathrm{H}-2)(5 \mu \mathrm{g} / \mathrm{mL})$ for $1 \mathrm{~h}$ prior to medium replacement. Targeted NPs (T-Au-[PLL-g-PEG] and T-Au-PEG) were then added at $80 \mu \mathrm{g} / \mathrm{mL}$ and cells incubated for $6 \mathrm{~h}$. Thereafter, cells were washed with cold PBS to remove residual medium and NPs. Cells were then trypsinized, lysed and centrifuged at $3000 \times g$ for $5 \mathrm{~min}$ to remove all cell debris. The resulting supernatant was then filtered through a 30-kDa MWCO Amicon ${ }^{\circledR}$ filter (Millipore) to remove other cellular contaminants. The filtrate was analyzed by NTA to determine the constituent nanoparticle concentration. Untreated cells were subjected to the same procedure and served as the control.

\subsection{Quantitative Determination of Nanoparticle Distribution by ICP-OES Analysis}

Caco-2, HeLa and MCF-7 cells $\left(2.0 \times 10^{5} / \mathrm{mL}\right)$ were seeded into $75 \mathrm{~cm}^{2}$ flasks, containing $25 \mathrm{~mL}$ EMEM and incubated overnight at $37{ }^{\circ} \mathrm{C}$ in $5 \% \mathrm{CO}_{2}$. Following medium replacement, $1.58 \mathrm{mg} / \mathrm{mL}$ of targeted and untargeted NPs were added, and cells incubated for $12 \mathrm{~h}$ at $37^{\circ} \mathrm{C}$ in $5 \% \mathrm{CO}_{2}$. The medium was then discarded, and the cells washed 3 times with cold PBS ( $\mathrm{pH}$ 7.4.) Cells were harvested by trypsinization and subsequent centrifugation at $300 \times g$ for $5 \mathrm{~min}$ at $4{ }^{\circ} \mathrm{C}$. The cell pellet was resuspended in $50 \mu \mathrm{L}$ of $10 \%$ cell lysis buffer $(1 \times)$ and placed on ice for $5 \mathrm{~min}$, with vortexing at $1 \mathrm{~min}$ intervals. Thereafter, $450 \mu \mathrm{L}$ of a $0.25 \mathrm{M}$ sucrose buffer $(\mathrm{pH} 7.4)$ was added and the cell suspension centrifuged twice at $700 \times g$ at $4{ }^{\circ} \mathrm{C}$ to remove cellular debris. The supernatant was further centrifuged at $12,000 \times g$ for $10 \mathrm{~min}$ at $4{ }^{\circ} \mathrm{C}$, to obtain the mitochondrial fraction (pellet), and cytoplasmic fraction (supernatant). The mitochondrial fraction was washed once in sucrose buffer at $10,000 \times \mathrm{g}$ for $10 \mathrm{~min}$ at $4{ }^{\circ} \mathrm{C}$. Both samples were digested in aqua regia $\left(2 \mathrm{~h}\right.$ at $\left.90^{\circ} \mathrm{C}\right)$ and subjected to inductively coupled plasma-optical emission spectrometry (ICP-OES) analysis for the determination of elemental gold concentration. ICP-OES was conducted on a Perkin Elmer Optima 5300 DV Optical Emission Spectrometer, and calibrated using 0, 50, 100, 200, 300, 400 and 500 parts per billion (ppb) of Au standard stock solution. Results were expressed in $\mathrm{ng} / \mu \mathrm{g}$ protein. The analysis was conducted in triplicate.

\subsection{MTT Assay}

The MTT cytotoxicity assay determines the percentage viability of a cell population as a function of the ability of live cells to reduce the MTT ((3-(4,5-dimethylthiazol-2-yl)-2,5diphenyltetrazolium bromide) to formazan by the NAD $(\mathrm{P}) \mathrm{H}$ dependent oxido-reductase enzyme system [70]. Confluent HEK293, Caco-2, HeLa, and MCF-7 cells were seeded $\left(2.0 \times 10^{3}\right.$ cells /well) into 96-well plates and incubated overnight at $37^{\circ} \mathrm{C}$ in $5 \% \mathrm{CO}_{2}$. The 
medium was then replaced, and NPs at varying concentrations were added, followed by incubation at $37^{\circ} \mathrm{C}$ in $5 \% \mathrm{CO}_{2}$ for $48 \mathrm{~h}$. At the end of the incubation period, the spent medium was replaced with fresh medium $(100 \mu \mathrm{L})$ containing $10 \mu \mathrm{L}(5 \mathrm{mg} / \mathrm{mL}$ in PBS) MTT reagent, and cells incubated as above for $4 \mathrm{~h}$. Control wells containing untreated cells were treated similarly. Thereafter, the MTT/medium was removed and $100 \mu \mathrm{L}$ DMSO was added to solubilize the formazan product. Absorbance was read against a DMSO blank at $540 \mathrm{~nm}$ using a Mindray MR-96A microplate reader (Vacutec, Hamburg, Germany). Cell viability was determined using the Equation below:

$$
\text { Cell Viability }(\%)=\left(\mathrm{OD}_{\text {treated cells })} /\left(\mathrm{OD}_{\text {control cells }}\right) \times 100\right.
$$

\subsection{Cell Cycle Analysis}

Caco-2, HeLa, and MCF-7 cells were seeded $\left(4.0 \times 10^{3}\right.$ cells/well) into 48-well plates and incubated for $12 \mathrm{~h}\left(37^{\circ} \mathrm{C}\right.$ and $\left.5 \% \mathrm{CO}_{2}\right)$. After medium replacement, cells were treated with both targeted and untargeted nanocomplexes, and free BA at the equimolar BA concentration of $25 \mu \mathrm{M}$, and incubated for $48 \mathrm{~h}$. The cells were then rinsed twice with cold PBS (pH 7.4), trypsinized and centrifuged at $300 \times g$ for $5 \mathrm{~min}$. Cells were then washed once with PBS, suspended in $70 \%$ cold ethanol, and then incubated for $3 \mathrm{~h}$ at $-20{ }^{\circ} \mathrm{C}$. Ethanol was removed by centrifugation $(300 \times g$ for $5 \mathrm{~min}$ ) and cells washed once with PBS. Thereafter, $200 \mu \mathrm{L}$ of the Muse ${ }^{\circledR}$ cell cycle reagent (containing premixed propidium iodide and RNase A), was added to each tube, and incubated for 30 min in the dark, at room temperature. Thereafter, cells were assessed using the Muse ${ }^{\mathrm{TM}}$ cell analyzer (Luminex Corporation, Austin, TX, USA).

\subsection{Mitopotential Assay}

Cells were seeded and treated as in Section 4.12. After a $48 \mathrm{~h}$ incubation, cells were trypsinized, centrifuged at $300 \times g$ for 5 min, washed once with PBS and resuspended in $100 \mu \mathrm{L}$ PBS. Approximately, $95 \mu \mathrm{L}$ Muse ${ }^{\circledR}$ mitopotential working solution was added to each tube, and cells incubated at $37^{\circ} \mathrm{C}$ for $20 \mathrm{~min}$. Thereafter, $5 \mu \mathrm{L}$ of 7 -aminoactinomycin $\mathrm{D}$ (7-AAD) was added, followed by incubation at room temperature for $5 \mathrm{~min}$. Mitochondrial membrane potential was assessed using the Muse ${ }^{\mathrm{TM}}$ cell analyzer.

\subsection{Caspase 3/7 Analysis}

Cells were seeded and treated as in Section 4.12. After incubation, cells were trypsinized, centrifuged and suspended in PBS. To a $50 \mu \mathrm{L}$ cell suspension, $5 \mu \mathrm{L}$ caspase- $3 / 7$ working reagent was added, and cells incubated at $37^{\circ} \mathrm{C}$ for $30 \mathrm{~min}$. Thereafter, $150 \mu \mathrm{L}$ 7-AAD working solution was added to each tube, thoroughly mixed, and analyzed using the Muse $^{\mathrm{TM}}$ cell analyzer.

\subsection{Apoptosis Assay}

A qualitative assessment of apoptosis induction in the selected normal and cancer cells was conducted by the acridine orange/ethidium bromide (AO/EB) dual staining method [28]. Cells were seeded as in Section 4.12 and incubated for $24 \mathrm{~h}$ at $37^{\circ} \mathrm{C}$ in $5 \% \mathrm{CO}_{2}$. Subsequently, the spent medium was replaced, and cells incubated for a further $48 \mathrm{~h}$ in the presence of the nanocomplexes and the free drug at their pre-determined $\mathrm{IC}_{50}$ concentrations. Untreated cells were used as controls. After the incubation the cells were washed twice with cold PBS, $15 \mu \mathrm{L}$ of the AO/EB dye mixture $(0.1 \mathrm{mg} / \mathrm{mL}: 0.1 \mathrm{mg} / \mathrm{mL})$ was added, and cells incubated for $5 \mathrm{~min}$ at ambient temperature. The cells were then washed with PBS to remove any unabsorbed dye and viewed under an Olympus fluorescence microscope (Wirsam Scientific and Precision Eq. LTD., Johannesburg, South Africa). Images were captured using a CC12 fluorescence camera and Analysis Five Software (Olympus Soft Imaging Solutions, Olympus, Japan) at 200× magnification. 


\subsection{Statistical Analysis}

Data are presented as mean \pm standard deviation (SD; $n=3$ ). Data were analyzed using GraphPad Prism Version 7.3 (GraphPad Software Inc., San Diego, CA, USA). A twoway ANOVA with a post-hoc Tukey test was used to identify significant differences among the groups, while differences between two values were performed using an unpaired Student's $t$ test. Differences were considered statistically significant at ${ }^{*} p<0.05$. All experiments were conducted in triplicate.

\section{Conclusions}

This study highlights the merit of NP application in drug delivery as a tool for improving drug bioavailability and pharmacokinetics. Furthermore, it provides a proof of concept for the subcellular delivery of therapeutics as an alternative approach to improving selectivity. As demonstrated in this study, the targeted T-Au-[PLL-g-PEG]-BA and T-Au-PEG-BA showed measurable impact at lower doses with negligible side effects in normal cells. They effected significant cytotoxicity in the Caco-2, HeLa and MCF-7 cell lines, compared to the free drug. The underlying mechanism involved the mitochondrial dependent pathway of apoptosis, with T-Au-[PLL-g-PEG]-BA being the most efficient of the nanocomplexes. This study also confirmed the laminin receptor-dependent uptake of EGCG-capped NPs and demonstrated their potential suitability as a platform for mitochondrial targeted delivery of therapeutics, following functionalization. Importantly, we established the proficiency of the T-Au-[PLL-g-PEG] nano-construct as a favorable platform for mitochondrial delivery of BA, with attention to its enabling physicochemical properties. Further research is however required, especially in vivo studies, to assess its potential for clinical applications.

Supplementary Materials: The following are available online at https:/ / www.mdpi.com/article/10 .3390 /ijms22105072/s1, Figure S1: ${ }^{1} \mathrm{H}$ NMR of PEG-CI in CDCl3; Figure S2: ${ }^{1} \mathrm{H}$ NMR PLL-g-PEG in D2O; Figure S3: ${ }^{1} \mathrm{H}$ NMR PLL-g-PEG-TPP+ in DMSO.

Author Contributions: Conceptualization, O.O., J.A. and M.S.; methodology, O.O., J.A. and A.D., software, O.O., J.A. and A.D.; validation, M.S. and A.D.; data curation, O.O., J.A. and A.D.; resources, M.S.; writing—original draft preparation, O.O. and J.A.; writing—review and editing, M.S. and A.D.; supervision, M.S.; project administration, M.S.; funding acquisition, M.S. All authors have read and agreed to the published version of the manuscript.

Funding: This research was funded by the National Research Foundation of South Africa, grant numbers 120455 and 129263.

Institutional Review Board Statement: Not applicable.

Informed Consent Statement: Not applicable.

Data Availability Statement: The data and contributions presented in the study are included in the article and Supplementary Materials. Further inquiries can be directed to the corresponding author.

Acknowledgments: The authors acknowledge members of the Nano-Gene and Drug Delivery group for advice and technical support.

Conflicts of Interest: The authors declare no conflict of interest.

\section{References}

1. Bray, F.; Ferlay, J.; Soerjomataram, I.; Siegel, R.L.; Torre, L.A.; Jemal, A. Global cancer statistics 2018: GLOBOCAN estimates of incidence and mortality worldwide for 36 cancers in 185 countries. CA Cancer J. Clin. 2018, 68, 394-424. [CrossRef]

2. Rais, L.; Masood, A. Sulfur and Nitrogen Co-ordinately Improve Photosynthetic Efficiency, Growth and Proline Accumulation in Two Cultivars of Mustard Under Salt Stress. J. Plant Biochem. Physiol. 2013, 1. [CrossRef]

3. Maney, V.; Singh, M. The Synergism of Platinum-Gold Bimetallic Nanoconjugates Enhances 5-Fluorouracil Delivery In Vitro. Pharmaceutics 2019, 11, 439. [CrossRef]

4. Wang, W.; Ning, J.-Y.; Liu, J.-T.; Miao, J.-Y.; Zhao, B.-X. A mitochondria-targeted ratiometric fluorescence sensor for the detection of hypochlorite in living cells. Dye. Pigment. 2019, 171, 107708. [CrossRef]

5. Tran, S.; DeGiovanni, P.; Piel, B.; Rai, P. Cancer nanomedicine: A review of recent success in drug delivery. Clin. Transl. Med. 2017, 6, 44. [CrossRef] [PubMed] 
6. $\quad$ Liu, C.-G.; Han, Y.-H.; Kankala, R.K.; Wang, S.-B.; Chen, A.-Z. Subcellular Performance of Nanoparticles in Cancer Therapy. Int. J. Nanomed. 2020, 15, 675-704. [CrossRef] [PubMed]

7. Akinyelu, J.; Singh, M. Nanomedicines for Subcellular Targeting: The Mitochondrial Perspective. Curr. Med. Chem. 2020, 27, 5480-5509. [CrossRef]

8. Neuzil, J.; Dong, L.-F.; Rohlena, J.; Truksa, J.; Ralph, S.J. Classification of mitocans, anti-cancer drugs acting on mitochondria. Mitochondrion 2013, 13, 199-208. [CrossRef]

9. Lee, K.L.; Shukla, S.; Wu, M.; Ayat, N.R.; El Sanadi, C.E.; Wen, A.M.; Edelbrock, J.F.; Pokorski, J.K.; Commandeur, U.; Dubyak, G.R.; et al. Stealth filaments: Polymer chain length and conformation affect the in vivo fate of PEGylated potato virus X. Acta Biomater. 2015, 19, 166-179. [CrossRef]

10. Hordyjewska, A.; Ostapiuk, A.; Horecka, A.; Kurzepa, J. Betulin and betulinic acid: Triterpenoids derivatives with a powerful biological potential. Phytochem. Rev. 2019, 18, 929-951. [CrossRef]

11. Alakurtti, S.; Mäkelä, T.; Koskimies, S.; Yli-Kauhaluoma, J. Pharmacological properties of the ubiquitous natural product betulin. Eur. J. Pharm. Sci. 2006, 29, 1-13. [CrossRef] [PubMed]

12. Fulda, S. Betulinic Acid for Cancer Treatment and Prevention. Int. J. Mol. Sci. 2008, 9, 1096-1107. [CrossRef]

13. Chintharlapalli, S.; Papineni, S.; Lei, P.; Pathi, S.; Safe, S. Betulinic acid inhibits colon cancer cell and tumor growth and induces proteasome-dependent and -independent downregulation of specificity proteins (Sp) transcription factors. BMC Cancer 2011, 11, 371. [CrossRef] [PubMed]

14. Ali-Seyed, M.; Jantan, I.; Vijayaraghavan, K.; Bukhari, S.N.A. Betulinic Acid: Recent Advances in Chemical Modifications, Effective Delivery, and Molecular Mechanisms of a Promising Anticancer Therapy. Chem. Biol. Drug Des. 2016, 87, 517-536. [CrossRef] [PubMed]

15. Kovarova, J.; Bajzikova, M.; Vondrusová, M.; Stursa, J.; Goodwin, J.; Nguyen, M.; Zobalova, R.; Pesdar, E.A.; Truksa, J.; Tomasetti, M.; et al. Mitochondrial targeting of $\alpha$-tocopheryl succinate enhances its anti-mesothelioma efficacy. Redox Rep. 2014, 19, 16-25. [CrossRef] [PubMed]

16. Dahoumane, S.A.; Jeffryes, C.; Mechouet, M.; Agathos, S.N. Biosynthesis of Inorganic Nanoparticles: A Fresh Look at the Control of Shape, Size and Composition. Bioengineers 2017, 4, 14. [CrossRef]

17. Castronovo, V.; Campo, E.; Brûle, F.A.V.D.; Claysmith, A.P.; Cioce, V.; Liu, F.-T.; Fernandez, P.L.; Sobel, M.E. Inverse Modulation of Steady-State Messenger RNA Levels of Two Non-Integrin Laminin-Binding Proteins in Human Colon Carcinoma. J. Natl. Cancer Inst. 1992, 84, 1161-1169. [CrossRef] [PubMed]

18. Basolo, F.; Pollina, L.; Pacini, F.; Fontanini, G.; Ménard, S.; Castronovo, V.; Bevilacqua, G. Expression of the Mr 67,000 laminin receptor is an adverse prognostic indicator in human thyroid cancer: An immunohistochemical study. Clin. Cancer Res. 1996, 2, 1777-1780. [PubMed]

19. Satoh, K.; Narumi, K.; Abe, T.; Sakai, T.; Kikuchi, T.; Tanaka, M.; Shimo-Oka, T.; Uchida, M.; Tezuka, F.; Isemura, M.; et al. Diminution of 37-kDa laminin binding protein expression reduces tumour formation of murine lung cancer cells. Br. J. Cancer 1999, 80, 1115-1122. [CrossRef]

20. Tachibana, H.; Koga, K.; Fujimura, Y.; Yamada, K. A receptor for green tea polyphenol EGCG. Nat. Struct. Mol. Biol. 2004, 11, 380-381. [CrossRef]

21. Shukla, R.; Chanda, N.; Zambre, A.; Upendran, A.; Katti, K.V.; Kulkarni, R.R.; Nune, S.K.; Casteel, S.W.; Smith, C.J.; Vimal, J.; et al. Laminin receptor specific therapeutic gold nanoparticles (198AuNP-EGCg) show efficacy in treating prostate cancer. Proc. Natl. Acad. Sci. USA 2012, 109, 12426-12431. [CrossRef] [PubMed]

22. Amgoth, C.; Phan, C.; Banavoth, M.; Rompivalasa, S.; Tang, G. Polymer Properties: Functionalization and Surface Modified Nanoparticles. In Role of Novel Drug Delivery Vehicles in Nanobiomedicine; IntechOpen: London, UK, 2020 ; p. 446.

23. Yang, D.H.; Kim, H.J.; Park, K.; Kim, J.K.; Chun, H.J. Preparation of poly-l-lysine-based nanoparticles with pH-sensitive release of curcumin for targeted imaging and therapy of liver cancer in vitro and in vivo. Drug Deliv. 2018, 25, 950-960. [CrossRef] [PubMed]

24. Zheng, M.; Pan, M.; Zhang, W.; Lin, H.; Wu, S.; Lu, C.; Tang, S.; Liu, D.; Cai, J. Poly( $\alpha$-l-lysine)-based nanomaterials for versatile biomedical applications: Current advances and perspectives. Bioact. Mater. 2021, 6, 1878-1909. [CrossRef] [PubMed]

25. Peltonen, L.; Singhal, M.; Hirvonen, J. Principles of nanosized drug delivery systems. In Nanoengineered Biomaterials for Advanced Drug Delivery; Elsevier BV: Amsterdam, The Netherlands, 2020; pp. 3-25.

26. Desai, R.; Mankad, V.; Gupta, S.; Jha, P. Size Distribution of Silver Nanoparticles: UV-Visible Spectroscopic Assessment. Nanosci. Nanotechnol. Lett. 2012, 4, 30-34. [CrossRef]

27. Mourdikoudis, S.; Pallares, R.M.; Thanh, N.T.K. Characterization techniques for nanoparticles: Comparison and complementarity upon studying nanoparticle properties. Nanoscale 2018, 10, 12871-12934. [CrossRef]

28. Akinyelu, J.; Singh, M. Folate-tagged chitosan-functionalized gold nanoparticles for enhanced delivery of 5-fluorouracil to cancer cells. Appl. Nanosci. 2018, 9, 7-17. [CrossRef]

29. Akinyelu, J.; Oladimeji, O.; Singh, M. Lactobionic acid-chitosan functionalised gold-coated poly(lactide-co-glycolide) nanoparticles for hepatocyte targeted gene delivery. Adv. Nat. Sci. Nanosci. Nanotechnol. 2020, 11, 045017. [CrossRef]

30. Coates, J. Interpretation of Infrared Spectra, A Practical Approach. In Encyclopedia of Analytical Chemistry: Applications, Theory and Instrumentation; John Wiley \& Sons Ltd.: Chichester, UK, 2000; pp. 10815-10837. 
31. Cinta-Pinzaru, S.; Dehelean, C.A.; Soica, C.; Culea, M.; Borcan, F. Evaluation and differentiation of the Betulaceae birch bark species and their bioactive triterpene content using analytical FT-vibrational spectroscopy and GC-MS. Chem. Central J. 2012, 6, 67. [CrossRef]

32. Clayton, K.N.; Salameh, J.W.; Wereley, S.T.; Kinzer-Ursem, T.L. Physical characterization of nanoparticle size and surface modification using particle scattering diffusometry. Biomicrofluidics 2016, 10, 054107. [CrossRef]

33. Fujimura, Y.; Sumida, M.; Sugihara, K.; Tsukamoto, S.; Yamada, K.; Tachibana, H. Green Tea Polyphenol EGCG Sensing Motif on the 67-kDa Laminin Receptor. PLoS ONE 2012, 7, e37942. [CrossRef] [PubMed]

34. Moodley, K.; Weiss, S.F.T. Downregulation of the Non-Integrin Laminin Receptor Reduces Cellular Viability by Inducing Apoptosis in Lung and Cervical Cancer Cells. PLoS ONE 2013, 8, e57409. [CrossRef]

35. Rzeski, W.; Stepulak, A.; Szymański, M.; Juszczak, M.; Grabarska, A.; Sifringer, M.; Kaczor, J.; Kandefer-Szerszeń, M. Betulin Elicits Anti-Cancer Effects in Tumour Primary Cultures and Cell LinesIn Vitro. Basic Clin. Pharmacol. Toxicol. 2009, 105, 425-432. [CrossRef] [PubMed]

36. Liu, X.; Jutooru, I.; Lei, P.; Kim, K.; Lee, S.-O.; Brents, L.K.; Prather, P.L.; Safe, S. Betulinic Acid Targets YY1 and ErbB2 through Cannabinoid Receptor-Dependent Disruption of MicroRNA-27a:ZBTB10 in Breast Cancer. Mol. Cancer Ther. 2012, 11, 1421-1431. [CrossRef] [PubMed]

37. Boukalova, S.; Rohlenova, K.; Rohlena, J.; Neuzil, J. Mitocans: Mitochondrially Targeted Anti-cancer Drugs. In Mitochondrial Biology and Experimental Therapeutics; Springer: Cham, Swtizerland, 2018; pp. 613-635.

38. Cai, Y.; Zheng, Y.; Gu, J.; Wang, S.; Wang, N.; Yang, B.; Zhang, F.; Wang, D.; Fu, W.; Wang, Z. Betulinic acid chemosensitizes breast cancer by triggering ER stress-mediated apoptosis by directly targeting GRP78. Cell Death Dis. 2018, 9, 636. [CrossRef] [PubMed]

39. Amoozgar, Z.; Yeo, Y. Recent advances in stealth coating of nanoparticle drug delivery systems. Wiley Interdiscip. Rev. Nanomed. Nanobiotechnol. 2012, 4, 219-233. [CrossRef]

40. Oladimeji, O.; Akinyelu, J.; Singh, M. Co-Polymer Functionalised Gold Nanoparticles Show Efficient Mitochondrial Targeted Drug Delivery in Cervical Carcinoma Cells. J. Biomed. Nanotechnol. 2020, 16, 853-866. [CrossRef] [PubMed]

41. Lazarus, G.G.; Singh, M. Cationic modified gold nanoparticles show enhanced gene delivery in vitro. Nanotechnol. Rev. 2016, 5, 425-434. [CrossRef]

42. Barenholz, Y. Liposome application: Problems and prospects. Curr. Opin. Colloid Interface Sci. 2001, 6, 66-77. [CrossRef]

43. Narainpersad, N.; Singh, M.; Ariatti, M. Novel Neo Glycolipid: Formulation into Pegylated Cationic Liposomes and

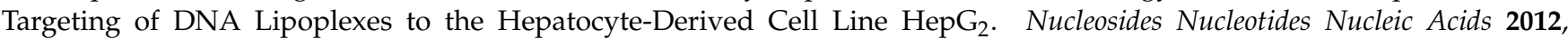
31, 206-223. [CrossRef] [PubMed]

44. Huang, X.; El-Sayed, M.A. Gold nanoparticles: Optical properties and implementations in cancer diagnosis and photothermal therapy. J. Adv. Res. 2010, 1, 13-28. [CrossRef]

45. Kudgus, R.A.; Walden, C.A.; McGovern, R.M.; Reid, J.M.; Robertson, J.D.; Mukherjee, P. Tuning Pharmacokinetics and Biodistribution of a Targeted Drug Delivery System Through Incorporation of a Passive Targeting Component. Sci. Rep. 2014, 4, 5669. [CrossRef] [PubMed]

46. Shen, S.; Wu, Y.; Liu, Y.; Wu, D. High drug-loading nanomedicines: Progress, current status, and prospects. Int. J. Nanomed. 2017, 12, 4085-4109. [CrossRef] [PubMed]

47. Marrache, S.; Dhar, S. The energy blocker inside the power house: Mitochondria targeted delivery of 3-bromopyruvate. Chem. Sci. 2014, 6, 1832-1845. [CrossRef] [PubMed]

48. Greish, K.; Mathur, A.; Bakhiet, M.; Taurin, S. Nanomedicine: Is it lost in translation? Ther. Deliv. 2018, 9, 269-285. [CrossRef] [PubMed]

49. Marrache, S.; Dhar, S. Engineering of blended nanoparticle platform for delivery of mitochondria-acting therapeutics. Proc. Natl. Acad. Sci. USA 2012, 109, 16288-16293. [CrossRef] [PubMed]

50. Shang, L.; Nienhaus, K.; Nienhaus, G.U. Engineered nanoparticles interacting with cells: Size matters. J. Nanobiotechnol. 2014, 12, 5. [CrossRef] [PubMed]

51. Rodríguez-Pulido, A.; Martín-Molina, A.; Rodríguez-Beas, C.; Llorca, O.; Aicart, E.; Junquera, E.; Sospedra, E.A. A Theoretical and Experimental Approach to the Compaction Process of DNA by Dioctadecyldimethylammonium Bromide/Zwitterionic Mixed Liposomes. J. Phys. Chem. B 2009, 113, 15648-15661. [CrossRef] [PubMed]

52. Maney, V.; Singh, M. An in vitro assessment of novel chitosan/bimetallic PtAu nanocomposites as delivery vehicles for doxorubicin. Nanomedicine 2017, 12, 2625-2640. [CrossRef] [PubMed]

53. Habib, S.; Daniels, A.; Ariatti, M.; Singh, M. Anti-c-myc cholesterol based lipoplexes as onco-nanotherapeutic agents in vitro. F1000Research 2020, 9, 770. [CrossRef]

54. Samimi, S.; Maghsoudnia, N.; Eftekhari, R.B.; Dorkoosh, F. Lipid-Based Nanoparticles for Drug Delivery Systems; Elsevier BV: Amsterdam, The Netherlands, 2019; pp. 47-76.

55. Foroozandeh, P.; Aziz, A.A. Insight into Cellular Uptake and Intracellular Trafficking of Nanoparticles. Nanoscale Res. Lett. 2018, 13, 1-12. [CrossRef]

56. Boukalova, S.; Stursa, J.; Werner, L.; Ezrova, Z.; Cerny, J.; Bezawork-Geleta, A.; Pecinova, A.; Dong, L.; Drahota, Z.; Neuzil, J. Mitochondrial Targeting of Metformin Enhances Its Activity against Pancreatic Cancer. Mol. Cancer Ther. 2016, 15, 2875-2886. [CrossRef] [PubMed] 
57. Piyaviriyakul, S.; Shimizu, K.; Asakawa, T.; Kan, T.; Siripong, P.; Oku, N. Anti-angiogenic Activity and Intracellular Distribution of Epigallocatechin-3-gallate Analogs. Biol. Pharm. Bull. 2011, 34, 396-400. [CrossRef] [PubMed]

58. Schroeder, E.K.; Kelsey, N.A.; Doyle, J.; Breed, E.; Bouchard, R.J.; Loucks, F.A.; Harbison, R.A.; Linseman, D.A. Green Tea Epigallocatechin 3-Gallate Accumulates in Mitochondria and Displays a Selective Antiapoptotic Effect Against Inducers of Mitochondrial Oxidative Stress in Neurons. Antioxid. Redox Signal. 2009, 11, 469-480. [CrossRef] [PubMed]

59. Dong, L.; Neuzil, J. Targeting mitochondria as an anticancer strategy. Cancer Commun. 2019, 39, 63-73. [CrossRef] [PubMed]

60. Saeed, M.E.M.; Mahmoud, N.; Sugimoto, Y.; Efferth, T.; Abdel-Aziz, H. Betulinic Acid Exerts Cytotoxic Activity Against Multidrug-Resistant Tumor Cells via Targeting Autocrine Motility Factor Receptor (AMFR). Front. Pharmacol. 2018, 9, 481. [CrossRef] [PubMed]

61. Rieber, M.; Rieber, M.S. Induction of p53 Without Increase in p21WAF1 in Betulinic Acid-Mediated Cell Death Is Preferential for Human Metastatic Melanoma. DNA Cell Biol. 1998, 17, 399-406. [CrossRef] [PubMed]

62. Chowdhury, A.R.; Mandal, S.; Mittra, B.; Sharma, S.; Mukhopadhyay, S.; Majumder, H.K. Betulinic acid, a potent inhibitor of eukaryotic topoisomerase I: Identification of the inhibitory step, the major functional group responsible and development of more potent derivatives. Med. Sci. Monit. 2002, 8, 254-265.

63. Kessler, J.H.; Mullauer, F.B.; De Roo, G.M.; Medema, J.P. Broad in vitro efficacy of plant-derived betulinic acid against cell lines derived from the most prevalent human cancer types. Cancer Lett. 2007, 251, 132-145. [CrossRef] [PubMed]

64. Pucci, B.; Kasten, M.; Giordano, A. Cell Cycle and Apoptosis. Neoplasia 2000, 2, 291-299. [CrossRef] [PubMed]

65. Alabsi, A.M.; Lim, K.L.; Paterson, I.C.; Ali-Saeed, R.; Muharram, B.A. Cell Cycle Arrest and Apoptosis Induction via Modulation of Mitochondrial Integrity by Bcl-2 Family Members and Caspase Dependence in Dracaena cinnabari-Treated H400 Human Oral Squamous Cell Carcinoma. BioMed Res. Int. 2016, 2016, 1-13. [CrossRef] [PubMed]

66. Li, J.; Li, T.-X.; Ma, Y.; Zhang, Y.; Li, D.-Y.; Xu, H.-R. Bursopentin (BP5) induces G1 phase cell cycle arrest and endoplasmic reticulum stress/mitochondria-mediated caspase-dependent apoptosis in human colon cancer HCT116 cells. Cancer Cell Int. 2019, 19, 130. [CrossRef] [PubMed]

67. Foo, J.B.; Yazan, L.S.; Tor, Y.S.; Wibowo, A.; Ismail, N.; How, C.W.; Armania, N.; Loh, S.P.; Ismail, I.S.; Cheah, Y.K.; et al. Induction of cell cycle arrest and apoptosis by betulinic acid-rich fraction from Dillenia suffruticosa root in MCF-7 cells involved p53/p21 and mitochondrial signalling pathway. J. Ethnopharmacol. 2015, 166, 270-278. [CrossRef] [PubMed]

68. Shen, H.; Liu, L.; Yang, Y.; Xun, W.; Wei, K.; Zeng, G. Betulinic Acid Inhibits Cell Proliferation in Human Oral Squamous Cell Carcinoma via Modulating ROS-Regulated p53 Signaling. Oncol. Res. Featur. Preclin. Clin. Cancer Ther. 2017, 25, 1141-1152. [CrossRef] [PubMed]

69. Neises, B.; Steglich, W. Simple Method for the Esterification of Carboxylic Acids. Angew. Chem. Int. Ed. 1978, 17, 522-524. [CrossRef]

70. Mosmann, T. Rapid colorimetric assay for cellular growth and survival: Application to proliferation and cytotoxicity assays. J. Immunol. Methods 1983, 65, 55-63. [CrossRef] 